\title{
Reducing Electrical Power Use With A Performance Based Incentive
}

\author{
M. Kathleen Nell
}

July 2004

Idaho National Engineering and Environmental Laboratory Bechtel BWXT Idaho, LLC 



\title{
Reducing Electrical Power Use with a Performance Based Incentive
}

\author{
M. Kathleen Nell
}

July 2004

Idaho National Engineering and Environmental Laboratory Sustainable Buildings and Applied Mechanics Department Idaho Falls, Idaho 83415

Prepared for the

U.S. Department of Energy

Departmental Energy Management Program

Under DOE Idaho Operations Office

Contract DE-AC07-99ID13727 


\section{Reducing Electrical Power Use with a Performance Based Incentive}

Prepared by:

Date:

(M. Kathie Nell)

Reviewed by: Date:

(Cheryl C. O'Brien) 


\section{SUMMARY}

This Departmental Energy Management Program (DEMP) funded Model Program Study developed out of a potential DOE-ID Performance Based Incentive for the Idaho National Engineering and Environmental Laboratory (INEEL), lasting from October 2001 through May 2002, which stressed reductions in electrical usage. An analysis of demand usage obtained from monthly INEEL Power Management electric reports revealed reductions in demand from a majority of the site areas. The purpose of this Model Program study was to determine the methods and activities that were used at these site areas to achieve the reductions in demand and to develop these demand reduction methods and activities into a Model Program that could be shared throughout the INEEL and DOE complex-wide for additional demand savings.

INEEL Energy Management personnel interviewed contacts from the eight areas which had achieved a consistent reduction in demand during the study period, namely, Idaho Nuclear Technology and Engineering Center (INTEC), Test Area North (TAN), Power Burst Facility (PBF), Test Reactor Area (TRA) including Advanced Test Reactor (ATR), Engineering Test Reactor (ETR), and Materials Test Reactor (MTR) areas, Central Facilities Area (CFA), Specific Manufacturing Capability (SMC), Radioactive Waste Management Complex (RWMC), and Argonne National Laboratory-West (ANLW).

The information that resulted from the interviews indicated that more than direct demand and energy reduction actions were responsible for the recorded reductions in demand. INEEL Energy Management identified five categories of actions or conditions that contributed to the demand reduction. These categories are Decontamination and Decommissioning (D\&D), employee actions, improvements, inactivation for maintenance, and processes. The following information details the findings from the study. 


\section{Contents}

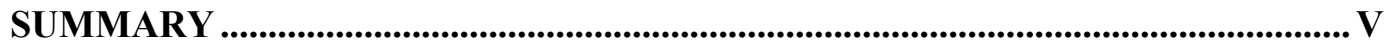

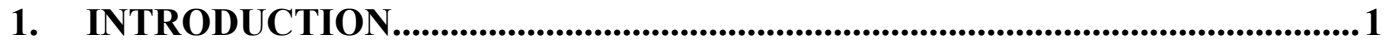

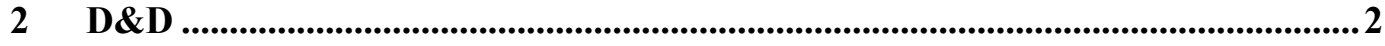

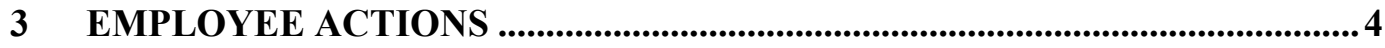

4 IMPROVEMENTS

5 INACTIVATION FOR MAINTENANCE ............................................................. 4

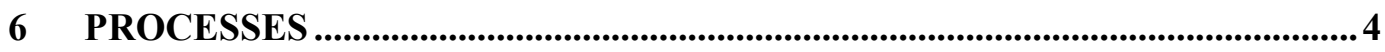

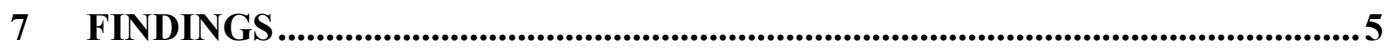

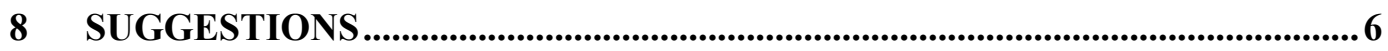

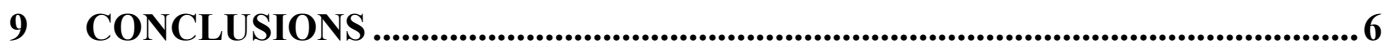

\section{SUMMARY OF TECHNIQUES TO REDUCE ELECTRICAL DEMAND}

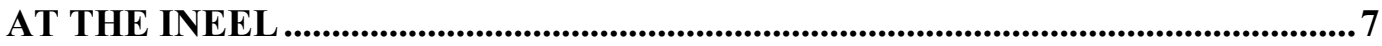

11 GENERAL ELECTRIC DEMAND REDUCING ACTIONS ........................9

APPENDIX A INTEC ENERGY CONSERVATION POSTERS.............................A-1

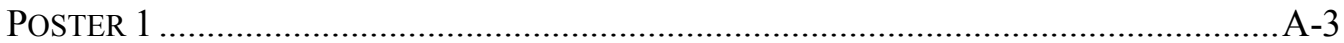

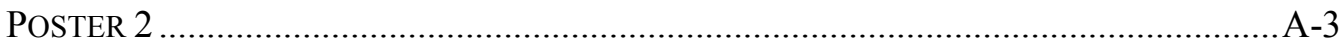

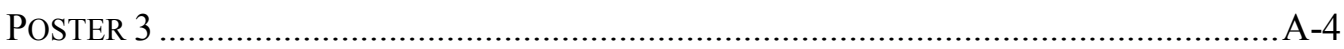

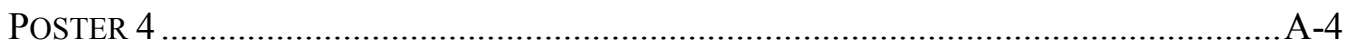

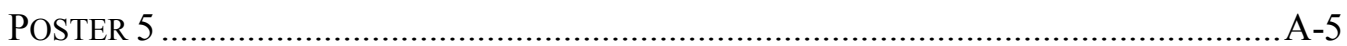

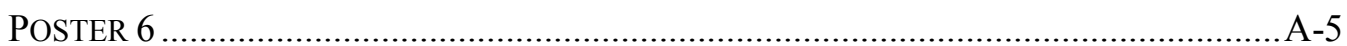

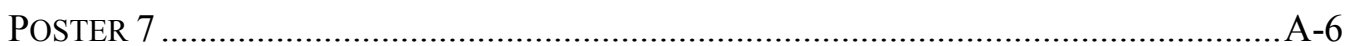

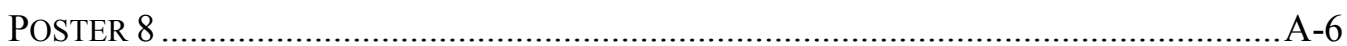

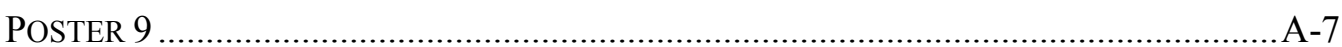

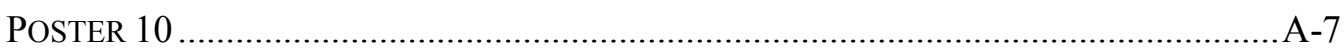

APPENDIX B BAR CHARTS COMPARING DEMAND USAGE FROM FYO0 TO

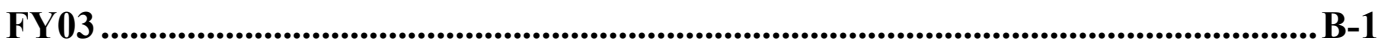

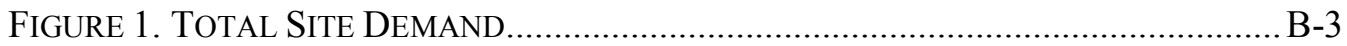

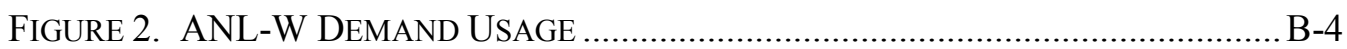

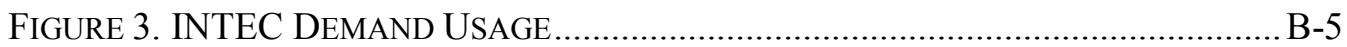

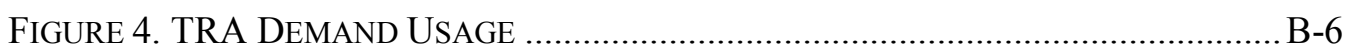

FIGURE 5. PBF DEMAND USAGE FY 00 THRU FY03 ............................................ B-7

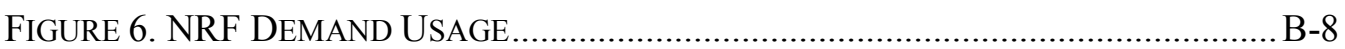

FIGURE 7. TAN DEMAND USAGE ..........................................................................

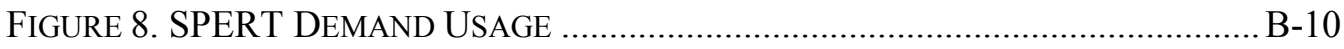

FIGURE 9. SMC DEMAND USAGE ...................................................................... B-11 


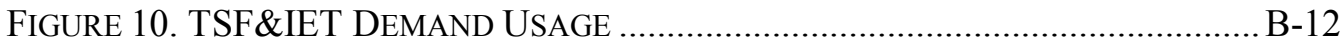

FIGURE 11. WERF DEMAND USAGE …................................................................. B-13

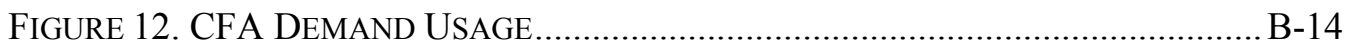

FIGURE 13. RWMC DEMAND USAGE .................................................................... 15

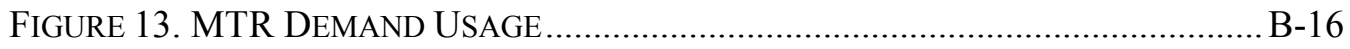

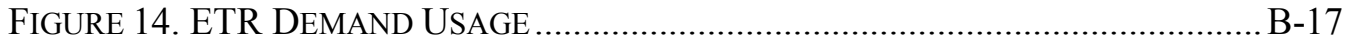

FIGURE 15. ATR DEMAND USAGE …................................................................ B-18 


\section{INTRODUCTION}

This Departmental Energy Management Program (DEMP) funded Model Program Study developed out of a potential DOE-ID Performance Based Incentive for the Idaho National Engineering and Environmental Laboratory (INEEL), lasting from October 2001 through May 2002, which stressed reduction in electric usage. The Performance Based Incentive was a draft agreement between DOE Idaho Operations and the Management and Operations Contractor, Bechtel BWXT Idaho to provide contract award fee for reducing energy costs at the INEEL. Although the draft agreement was not included in the final Performance Based Agreement, energy savings were realized during the period of time the draft agreement existed. The purpose of this Model Program study was to determine the methods and activities that were used at selected INEEL site areas to achieve the reductions in demand, which occurred during the eight months of the potential PBI, and to develop these demand reduction methods and activities into a Model Program that could be shared throughout the INEEL and Department of Energy - (DOE) complex-wide for additional demand savings.

The study was started on June 21,2003 . The first step in the study was to gather data to identify which areas achieved the greatest reduction in electric demand load over the study period of October 1 , 2001 to September 30, 2002. The entire year was chosen for study rather than just the eight months of discussion for the potential Performance Based Incentive to see if, and how, demand changed after reduction in usage was no longer being stressed. A spreadsheet was created from actual demand records acquired from INEEL Power Management for eight main areas and seven sub-areas at the INEEL.

The main areas analyzed were:

1. Argonne National Laboratory-West (ANL-W)

2. Idaho Nuclear Technology and Engineering Center (INTEC)

3. Test Reactor Area (TRA)

4. Naval Reactors Facility (NRF)

5. Test Area North (TAN)

6. Special Power Excursion Reactor Test (SPERT)

7. Central Facilities Area (CFA)

8. Radioactive Waste Management Complex (RWMC).

Sub-areas analyzed were:

TRA

1. Materials Test Reactor (MTR)

2. Engineering Test Reactor (ETR)

3. Advanced Test Reactor (ATR)

TAN

4. Test Support Facility and Initial Engine Test (TSF\&IET)

5. Specific Manufacturing Capability (SMC) 
SPERT
6. Power Burst Facility (PBF)
7. Waste Experimental Reactor Facility (WERF)

Fiscal Years 2000, 2001, and 2003 were also analyzed to eliminate the possibility that observed reductions were of a cyclic nature. A bar chart was then created for each area comparing demand usage for Fiscal Years 2000 through 2003. See Appendix B, Figures 1-16 for bar charts comparing demand usage by year for the selected areas. Areas with consistent reductions in demand were selected as areas of study and contacts were identified in these areas. Contacts were also identified for areas that did not show consistent reductions in demand, but that contributed highly to the demand load in case helpful suggestions could be found from these large users.

INEEL Energy Management personnel interviewed contacts from MTR, INTEC, TAN, PBF, SPERT, TRA/ATR, CFA, SMC, RWMC, and ANL-W using a set of questions created from the results of the September 2001, Site Power Load Study, INEEL/INT-01-01276. The 2001 study evaluated energy usage and costs at INTEC, TRA, and CFA, the three largest electricity users at the INEEL desert site, and included a list of recommendations that could help reduce energy usage and peak demand. Since any load reduction practices that had been used during FY2002 were of interest, the interview questions also served to determine if any of the recommendations had actually been implemented since publication of the study in 2001 .

The results of this interview process were analyzed to identify recurring topics and were then separated into the resultant categories: Decontamination and Decommissioning (D\&D), employee actions, improvements to buildings, maintenance of equipment, and processes.

\section{D\&D}

There has been a strong push at the INEEL to D\&D inactive buildings in order to save energy and use space wisely. With these goals in mind, several buildings at the site scheduled for D\&D were inactivated during FY 2002.

Inactivation follows a graded approach depending upon the type of building. For the purpose of this study, in inactivated buildings, personnel have been moved out of the buildings, and water and electricity have been disconnected. In evacuated buildings, the building has been emptied of occupants, but still has active electrical and water systems. The following buildings were either inactivated or evacuated during the period of our study.

\section{CFA Buildings Inactivated:}

$$
\begin{aligned}
& \text { CF-1610 - 4,700 square feet } \\
& \text { CF-646 - 223 square feet } \\
& \text { CF-660 - 5,454 square feet } \\
& \text { CF-667 - 6,257 square feet } \\
& \text { CF-684 - 256 square feet }
\end{aligned}
$$


INTEC Buildings Inactivated:

CPP-608 - 2,600 square feet

CPP-665 - 19,200 square feet

CPP-687 - 24,034 square feet

CPP-688 - 3,596 square feet

CPP-689 - 100 square feet

CPP-690 - 1,300 square feet

CPP-696-651 square feet

CPP-T-1 - 900 square feet

CPP-T-5 - 900 square feet

CPP-TB-4 - 4,800 square feet

TAN Buildings Inactivated:

TAN-642 - 128 square feet

TAN-645 - 8,146 square feet

TAN-646 - 16,870 square feet

TRA Buildings Inactivated:

TRA-613A - 577 square feet

TRA-613B - 577 square feet

TRA-615 - 36 square feet

TRA-618 - 15,190 square feet

TRA-631 - 336 square feet

TRA-663 - 1,120 square feet

TRA-664 - 800 square feet

\section{PBF Buildings Inactivated:}

PBF-601 - 8,048 square feet

PBF-626- 586 square feet

PBF-616 - 820 square feet

PBF-617-368 square feet

\section{Buildings evacuated but not inactivated (power and water still on):}

TRA-647 (ETR Office Building) - 11,793 square feet

CPP-674 - 455 square feet

CPP-675- 858 square feet 


\section{Total Square Footage of buildings inactivated - 52,289 \\ Total Square Footage of buildings evacuated - 13,106}

Inactivated buildings have the power and water deactivated, and therefore are not adding to the hourly demand. Although evacuated buildings still are connected to power and water, they are in a reduced energy usage state and therefore are saving on the demand load even though some electricity must be used to heat the buildings sufficiently to prevent the water pipes from freezing in cold weather.

\section{EMPLOYEE ACTIONS}

Employee actions contributed to reduced electric consumption, but had little effect on overall peak demand. At INTEC, (see Appendix B, Figure 3) the area with the largest annual reduction in demand during the study period, employees were encouraged with posters to conserve energy, (see Appendix A, Posters 1-10) and to use power save and other energy saving features on their computers, monitors, scanners, copiers, and printers. They were also sent e-mail notices with reminders to turn out lights at night and before leaving on the weekends. Security personnel were instructed to turn off lights during their rounds. SMC incorporated turning off lights and ramping down supply fans into their round sheets to reduce electric usage. In other site areas with complex processes, experienced personnel were required to shut off lights and other equipment, so necessary processes were not interrupted.

\section{IMPROVEMENTS}

Improvements to the buildings increased efficiency and lowered demand usage. In response to the potential Performance Based Incentive, weather stripping was replaced and / or added, occupancy sensors were installed, and a portion of a degraded steam heat was replaced with a more efficient technology. INTEC completed a utility upgrade project to reduce demand and bring the system up to code. As part of the upgrade, some equipment was removed and / or replaced.

\section{INACTIVATION FOR MAINTENANCE}

Some of the reductions in demand were a result of maintenance-type activities. Power was shut off to TRA-638 for a number of months; the air conditioning to TRA-678 was shut down during one cooling season, the ATR reactor was down during a large portion of the year, and at SMC, machines that were not being used were shut down.

\section{PROCESSES}

Changes in the processes around the INEEL resulted in additional demand usage savings, although these process changes were inspired by a need for energy conservation rather than the potential Performance Based Incentive. The Coal Fired Plant at INTEC was shut down during the period of the study, two $125 \mathrm{hp}$ motors that ran chillers were disconnected, and steam was discontinued for the summer in CPP-637, 620, 665, 606, 630, 668, 699, 666, 660, 687, and 663.

Boiler steam pressure was evaluated at a reduced pressure of $100 \mathrm{psi}$. The results were determined acceptable; therefore, operating procedures were revised to include this reduced boiler steam pressure setting. The boilers are now operating regularly at the lower pressure to save on both costs and energy.

The Calciner at INTEC was shut down before the beginning of the study period, but some of the reductions from this shutdown can be seen in the barchart comparison for INTEC. 
At TRA, there are 3 diesel-powered generators, which run when the reactor is operating and help to reduce peak electric demand. One of the three is an emergency generator that starts automatically for an upset condition. Of the remaining two diesel generators, one generator runs continuously during reactor operation. Although running the diesel-powered generators reduces peak electric demand, the main purpose of these generators is to supply power to vital plant equipment necessary to support a safe plant shutdown in the event of a loss of commercially supplied power.

At PBF, the incinerator (PBF-609) underwent RCRA closure. Blowers 1, 2, 5, 6 \& 7 were put offline. The remaining two blowers, 3 and 4, are being operated one at a time for ventilation. In PBF-622, there were two RCRA units closed. The blowers were also shut down to these two units. Lights were also turned down during back shifts and weekends.

\section{FINDINGS}

\subsection{Turning off lights and electronic equipment}

In general, most areas did not have much success getting employees to turn off lights when leaving their offices. INEEL Energy Management personnel investigated the possibility of reducing demand by turning off lights in offices with or near windows, but found that this was not practical in most cases. Many areas of the site have light switches that are not conveniently located, and in some cases, lights are controlled directly from the breaker. Turning off lights near the windows to provide daylighting controls would require rewiring of the current lighting configuration. Often at PBF and SMC, multiple hardwalled offices are controlled by just one switch. Demand could possibly be reduced by rewiring these offices so occupants have individual control over the lighting in their offices. Another option would be to install occupancy sensors in the offices, so that when the offices are unoccupied the lights would turn off automatically.

Shutting down computers at the end of the day and when leaving for the weekend is a good energy conservation measure, but has little effect on demand. However, enabling power saver modes on computers can help demand, and require little thought from employees once the settings are in place.

\subsection{Altering pumping schedules}

Pumping schedules were also investigated as a possible way to reduce demand. At INTEC, there are two sets of water tanks and the pumps turn on when the water in Tank 600/08 is at 19 feet and turns off when the water is at 35 feet in Tank 611/12. The deep well pumps are on line for 4 to 5 hours each run and they start up every 11-12 hours. This figures out to an 8-9 hour run time in 24 hours at the present usage. Therefore, if the tanks were verified to be full before the peak time, then it appears that it would be possible to delay turning on the pumps until after the peak demand period.

At CFA, firewater and potable water are the same. Interviews indicated that there is adequate water during the winter to alter pumping schedules around peak demand times, but in summer, there is a lot of water used for irrigation. Alteration of pumping schedules during summer would possibly require irrigation to be scheduled for evening hours. It might be beneficial to do a small study of when the deep well pumps turn on in the months of October thru April or May to see when, and/or if, the wells turn on during the peak times.

\subsection{Fan usage}

In CPP-666, there was a large process that is no longer in use, but the ventilation rate of 90,000 $\mathrm{cfm}$ for the building has not changed. There are two main fans that use $75 \mathrm{hp}$ motors and two supply fans 
that use $125 \mathrm{hp}$ motors. A closer analysis might reveal that the ventilation rates may be reduced. If half of the airflow could be reduced, and assuming an $80 \%$ load on the fans and an $80 \%$ efficiency of the motors, this calculates to a savings of $1,307,887 \mathrm{kWh}$. Multiplying by $\$ .06$ per $\mathrm{kWh}$ could save $\$ 78,473$ per year just by turning off two fans.

\section{SUGGESTIONS}

In each interview, INEEL Energy Management asked the various contacts for suggestions to reduce demand that are not currently being implemented. The majority of responses were ideas to make improvements to the existing buildings such as adding more convenient light switches, installing occupancy sensors, insulation and weather stripping on doors and windows, replacing incandescent lights with fluorescents, installing more efficient heating systems, adding separate power meters on buildings, and shutting off power to areas not being used. Area specific suggestions included updating the HVAC system at CPP-637 with an automatic thermostat, and at TRA-641, converting the fire water system to a dry pipe system, isolating the potable water, and deactivating the power. Even though TRA-641 has been evacuated, because of water in the existing pipes, it is necessary to heat the building enough to prevent the pipes from freezing. By isolating the building from the potable water system and changing to a dry pipe system, the power can be turned off without danger of freezing. This will save on the electricity currently being used to keep the building warm. The contact at TRA suggested reducing the demand by altering the big motors to have soft starts, which involves attaching capacitors to the motors so that when they start they don't draw full starting current.

\section{CONCLUSIONS}

A combination of conditions contributed to the demand reduction that occurred during the eight months that the draft Performance Based Incentive was being evaluated. It was assumed that the reduction in demand was a result of actual demand reduction activities, but those activities apparently only contributed to a small portion of the overall demand reduction. Twenty-nine buildings totaling 52,289 square feet were inactivated as part of a D\&D effort, and three buildings totaling 13,106 square feet, were evacuated. The Coal Fire Plant at INTEC was shut down as well as the PBF incinerator, PBF609, which underwent RCRA closure. The 3100 meter project at RWMC ended, which used a substantial amount of electricity, a project which operated 10 hour days, 4 days a week to begin with, eventually going to a 24 hour, 7 day a week schedule. Power was shut off to TRA-638 for several months for maintenance, and the air conditioning to TRA-678 was shut down for scheduled maintenance during one cooling season. The Advanced Test Reactor (ATR) was down for maintenance throughout much of the study period, which reduced demand partially due to not running the two $2000 \mathrm{hp}$-pumps that operate while the reactor is operating, and at INTEC, two $125 \mathrm{hp}$ motors that ran chillers were disconnected.

Some actions were implemented to reduce energy costs that in some cases also reduced demand such as shutting off the general steam supply earlier than normal to reduce costs. TRA operated its diesel-powered generators to offset demand costs, and at SMC, supply fans were ramped down at night and machines that were not being used were completely shut down. In addition, employees were encouraged to use power saver settings on their computers and to turn off lights whenever possible.

In summation, our study determined that the documented demand reduction during FY02 was caused, not by load reduction strategies at the INEEL site, but primarily as a consequence of closure activities, maintenance, and general process modifications. However, this study has raised awareness within the INEEL about what actually affects demand and what techniques can be used to reduce demand in the future. Finally, the study has identified several techniques or methods that will result in reduced electrical demand and consumption costs. 
The following list summarizes the techniques identified and/or used at the INEEL during this study to reduce electrical demand. The techniques are grouped by the following categories: Equipment, Lighting, Maintenance, Operations, and Major Ticket Items.

\section{SUMMARY OF TECHNIQUES TO REDUCE ELECTRICAL DEMAND AT THE INEEL}

\begin{tabular}{|c|c|c|}
\hline & Description & Category \\
\hline 1. & $\begin{array}{l}\text { Turn off unneeded equipment including computers, office } \\
\text { equipment, tools, and lights }\end{array}$ & Equipment \\
\hline 2. & Program and use power saver modes on computers & Equipment \\
\hline 3. & $\begin{array}{l}\text { Purchase equipment with low-standby power settings of }<2 \\
\text { watts }\end{array}$ & Equipment \\
\hline 4. & $\begin{array}{l}\text { Install occupancy sensors in offices and all common areas } \\
\text { such as conference rooms, and restrooms }\end{array}$ & Lighting \\
\hline 5. & $\begin{array}{l}\text { Install more conveniently placed light switches, so } \\
\text { employees have better control of lights in offices }\end{array}$ & Lighting \\
\hline 6. & Replace all incandescent lights with fluorescent lights & Lighting \\
\hline 7. & $\begin{array}{l}\text { Repair or replace weather stripping around doors and } \\
\text { windows }\end{array}$ & Maintenance \\
\hline 8. & $\begin{array}{l}\text { Clean/or replace HVAC filters to optimize system } \\
\text { performance and reduce energy costs by reducing air flow } \\
\text { restrictions }\end{array}$ & Maintenance \\
\hline 9. & $\begin{array}{l}\text { Modify large motors with soft starts, which involves } \\
\text { attaching capacitors to the motors so that when they start } \\
\text { they don't draw a full starting current }\end{array}$ & Maintenance \\
\hline 10 . & $\begin{array}{l}\text { Install separate power meters on buildings so that excessive } \\
\text { energy use can be more easily located and mitigated }\end{array}$ & Maintenance \\
\hline 11. & $\begin{array}{l}\text { Operate diesel-power generators to offset demand where } \\
\text { possible }\end{array}$ & Operations \\
\hline 12. & $\begin{array}{l}\text { Alter pumping schedules to fill water tanks just before or } \\
\text { just after peak demand times. Generally, peak electrical } \\
\text { loads occur at mid morning during the winter and early } \\
\text { afternoon during the summer. }\end{array}$ & Operations \\
\hline 13. & $\begin{array}{l}\text { Reschedule irrigation to evening hours, which are outside } \\
\text { of the typical peak demand period at the INEEL }\end{array}$ & Operations \\
\hline
\end{tabular}




\begin{tabular}{|cl|l|}
\hline \multicolumn{1}{|c|}{ Description } & Category \\
\hline 14. & $\begin{array}{l}\text { Analyze fan usage and determine if it is possible to use } \\
\text { fans for less time, or, where there is more than one fan, to } \\
\text { shut down one or more without affecting necessary air flow }\end{array}$ & Operations \\
\hline 15. & $\begin{array}{l}\text { Close down buildings and shut off power to areas that are } \\
\text { not being used }\end{array}$ & Operations \\
\hline $16 . \quad \begin{array}{l}\text { Install more efficient heating systems (Energy Star when } \\
\text { available) }\end{array}$ & Major ticket items \\
\hline 17. & $\begin{array}{l}\text { Convert the fire water system at TRA-641 to a dry pipe } \\
\text { system, isolate potable water system, and turn off heat to } \\
\text { the building. }\end{array}$ & Major ticket items \\
\hline
\end{tabular}


Using the results of this Load Management Study, a second list was created that could be applied to reduce demand at other DOE sites. This list includes items that the INEEL has already implemented on a regular basis to reduce demand costs, but excludes the building-specific suggestions in the INEEL site list. It is hoped that this list will be used as a basis for developing demand reduction techniques at other DOE-sites.

\section{GENERAL ELECTRIC DEMAND REDUCING ACTIONS}

The following list describes general actions that can be taken at any facility interested in reducing its electric demand load.

\begin{tabular}{|c|c|c|}
\hline \multicolumn{2}{|r|}{ Description } & \multirow{2}{*}{$\begin{array}{l}\text { Category } \\
\text { Equipment }\end{array}$} \\
\hline 1. & Turn off unneeded equipment. & \\
\hline 2. & Use power saver modes on computers. & Equipment \\
\hline 3. & $\begin{array}{l}\text { Encourage employees to shut down computers, printers, and task } \\
\text { lighting when leaving offices for more than } 30 \text { minutes and when they } \\
\text { leave at night and on weekends. }\end{array}$ & Equipment \\
\hline 4. & $\begin{array}{l}\text { Buy Energy Star products when replacing appliances, electronics, and } \\
\text { heating and cooling systems. }\end{array}$ & Equipment \\
\hline 5. & $\begin{array}{l}\text { Purchase equipment with low-standby power settings of }<2 \text { watts. The } \\
\text { following link provides some guidance on purchasing low standby } \\
\text { power devices } \\
\text { (http://www.eere.energy.gov/femp/technologies/eeproducts.cfm). A } \\
\text { link to a list of FEMP approved low power standby devices is found at: } \\
\text { http://oahu.lbl.gov/. }\end{array}$ & Equipment \\
\hline \multirow[t]{4}{*}{6.} & $\begin{array}{l}\text { Install occupancy sensors in offices, common area rooms, and } \\
\text { restrooms. Motion sensor controls should be specified to control all } \\
\text { common use areas. The following types of technologies are available: }\end{array}$ & \multirow[t]{4}{*}{ Lighting } \\
\hline & $\begin{array}{l}\text { Passive Infrared (PIR): Offices, classrooms, conference rooms, } \\
\text { and others that provide a direct line of sight to the sensor. }\end{array}$ & \\
\hline & $\begin{array}{l}\text { - Ultrasonic: Restrooms, libraries, and others where the area is } \\
\text { typically cluttered or equipment and machinery can block a direct } \\
\text { line of sight. }\end{array}$ & \\
\hline & $\begin{array}{l}\text { - Dual Technology: Cubicle areas, and other areas with difficult } \\
\text { environments such as high or inconsistent air flow. }\end{array}$ & \\
\hline 7. & $\begin{array}{l}\text { Replace incandescent lights with fluorescent lights. Replace the T-12 } \\
\text { fluorescent lighting components with energy efficiency T-8 lamps and } \\
\text { electronic ballasts. }\end{array}$ & Lighting \\
\hline 8. & Replace insulation and weather stripping around doors and windows. & Maintenance \\
\hline
\end{tabular}




\begin{tabular}{|c|c|c|}
\hline & Description & Category \\
\hline 9. & $\begin{array}{l}\text { Clean/or replace furnace and/or air conditioner filters to optimize } \\
\text { heating and cooling operation. }\end{array}$ & Maintenance \\
\hline 10. & $\begin{array}{l}\text { Close down buildings and shut off power to areas that are not being } \\
\text { used. }\end{array}$ & Operations \\
\hline 11. & $\begin{array}{l}\text { Reschedule landscape watering for evenings after commercial peak } \\
\text { demand times. }\end{array}$ & Operations \\
\hline
\end{tabular}


Appendix A

INTEC Energy Conservation Posters 


\section{Appendix A \\ INTEC Energy Conservation Posters}

The following posters were created by Kim Radford to encourage employees to conserve energy at both work and home. They were created in response to a combination of factors including higher electricity costs, the energy shortage in California, and the proposed DOE Performance Based Incentive, which committed the INEEL to reduce consumption by $10 \%$ through town and site buildings. The posters, as well as e-mail reminders to employees, resulted in a noticeable reduction in energy consumption during the study period October 2001 to September 2002. 
A-2 


\section{Poster 1}

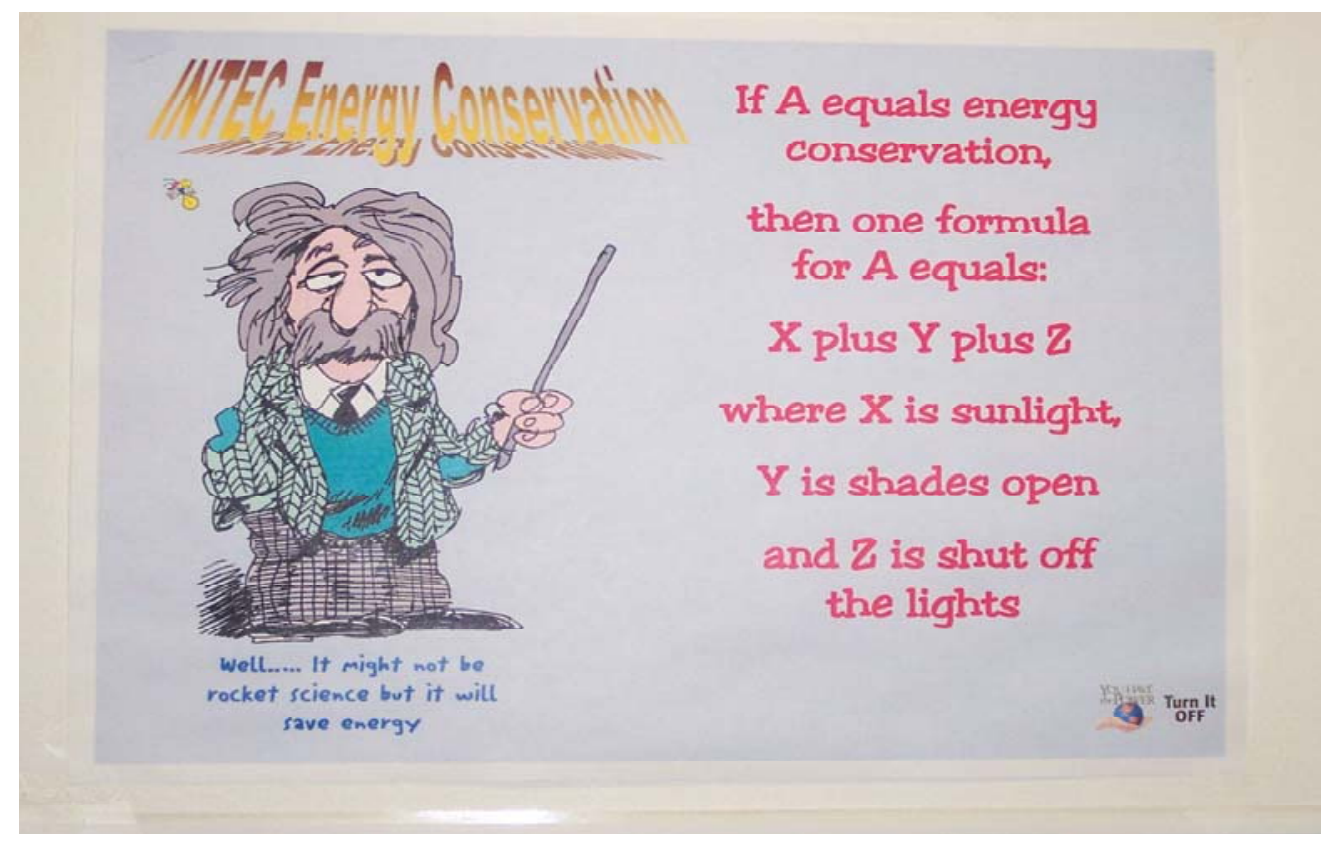

\section{Poster 2}

\section{INTEC Fingrgy Conservation}

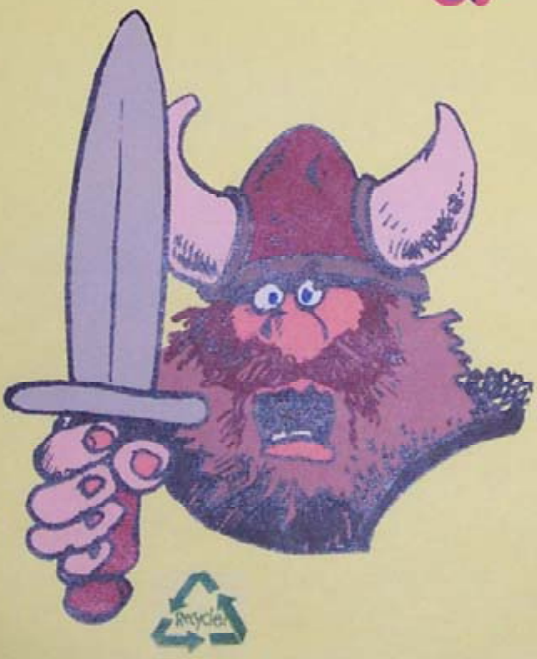

Your father was right, he doesn't own the electric company so Please TURN your office lights and equipment OFF when you leave for the night. 


\section{Poster 3}

As the days get

longer use the natural light from your office window.

Natural light is more efficient than electric not to mention free
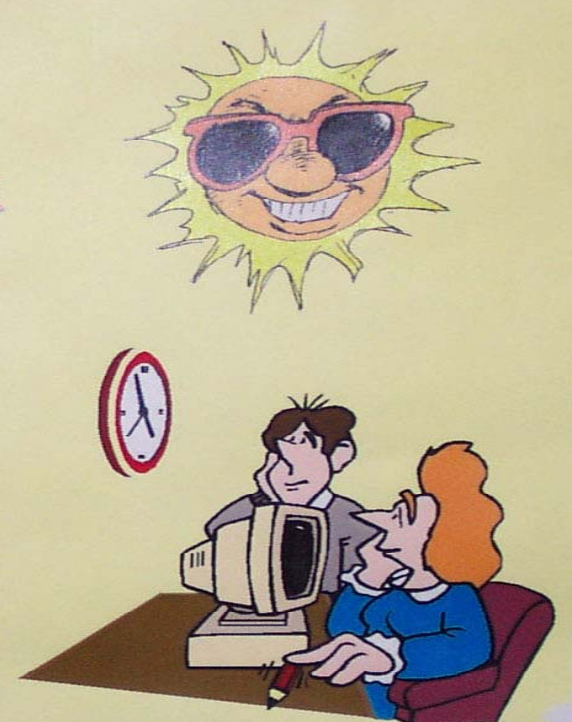

\section{Poster 4}

\section{INTEC Energ Conservation}
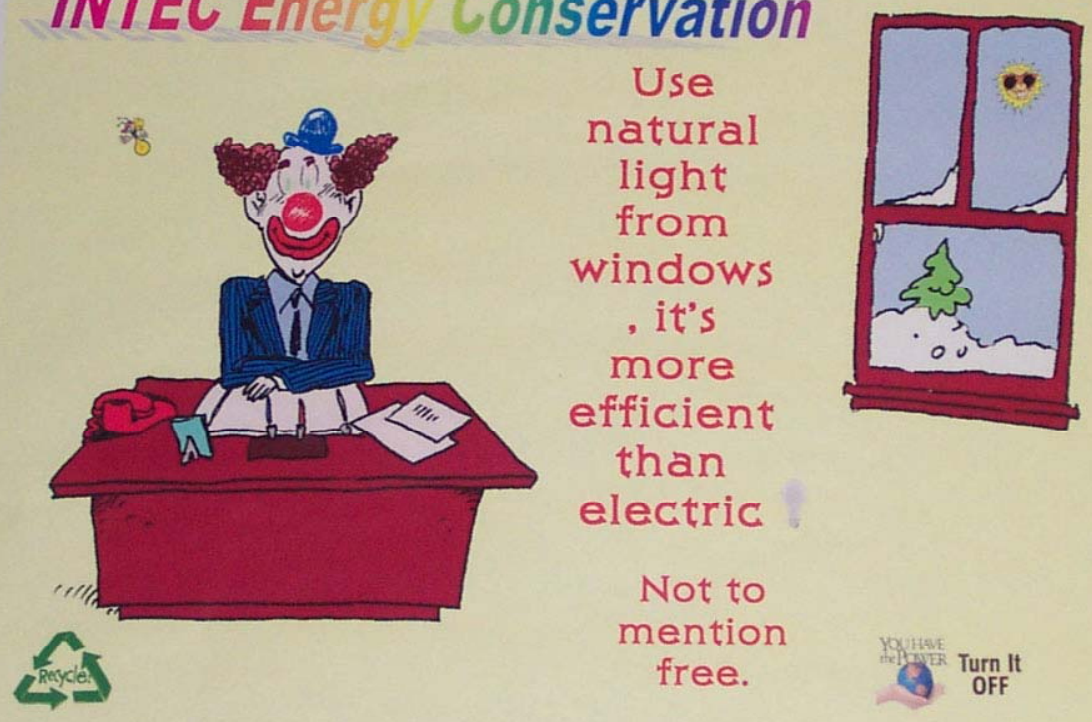

9. Tumpt 


\section{Poster 5}

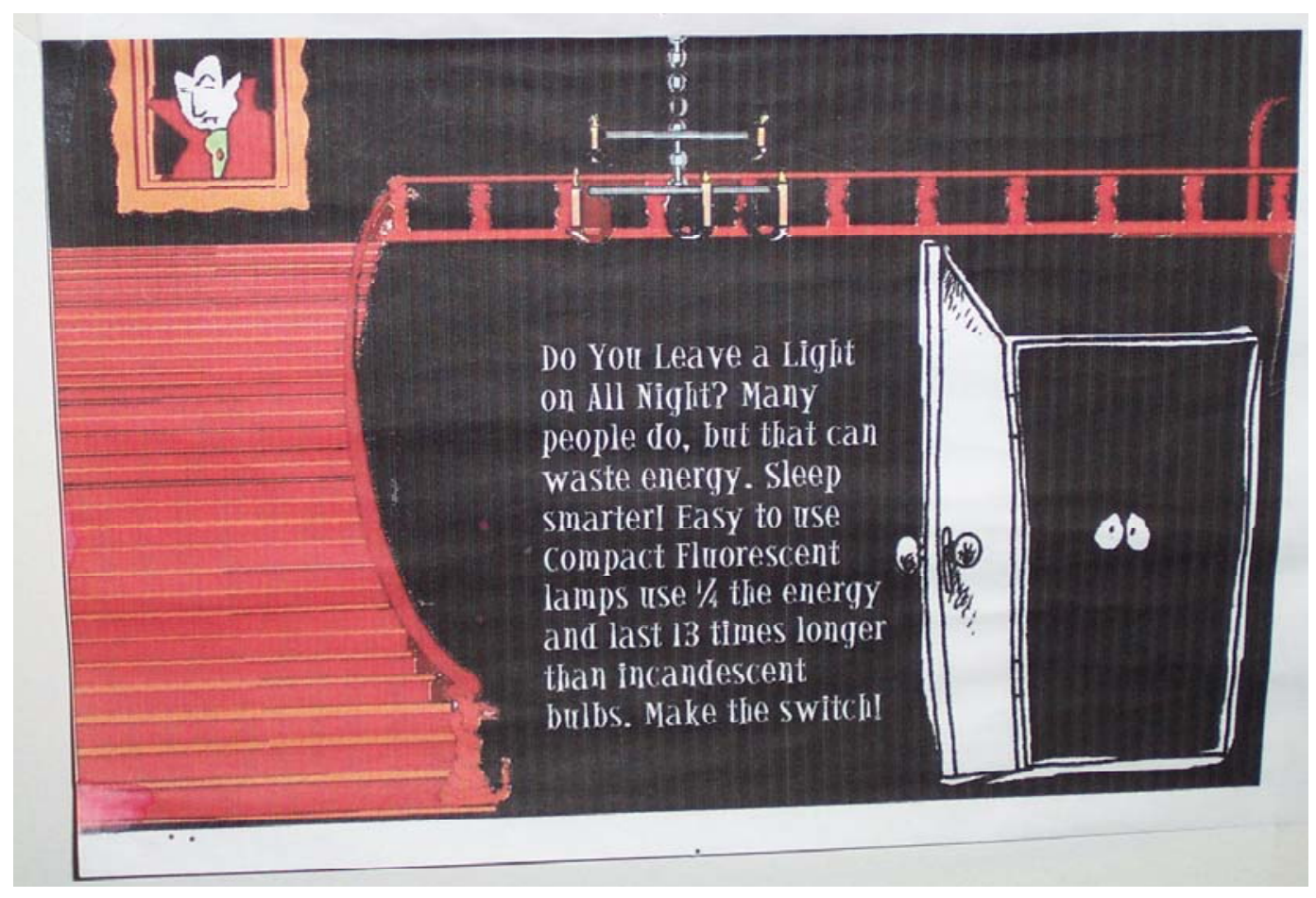

\section{Poster 6}

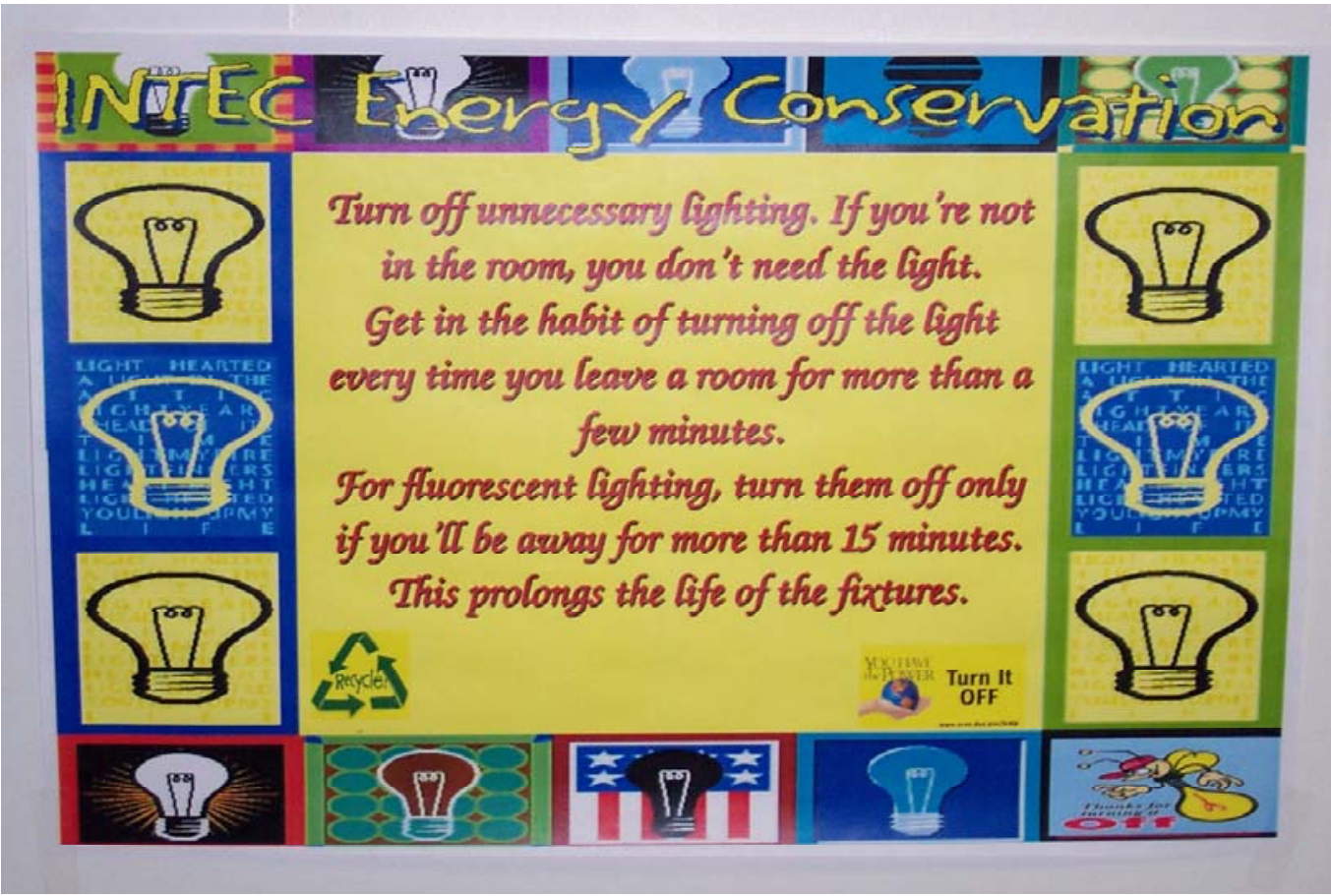




\section{Poster 7}

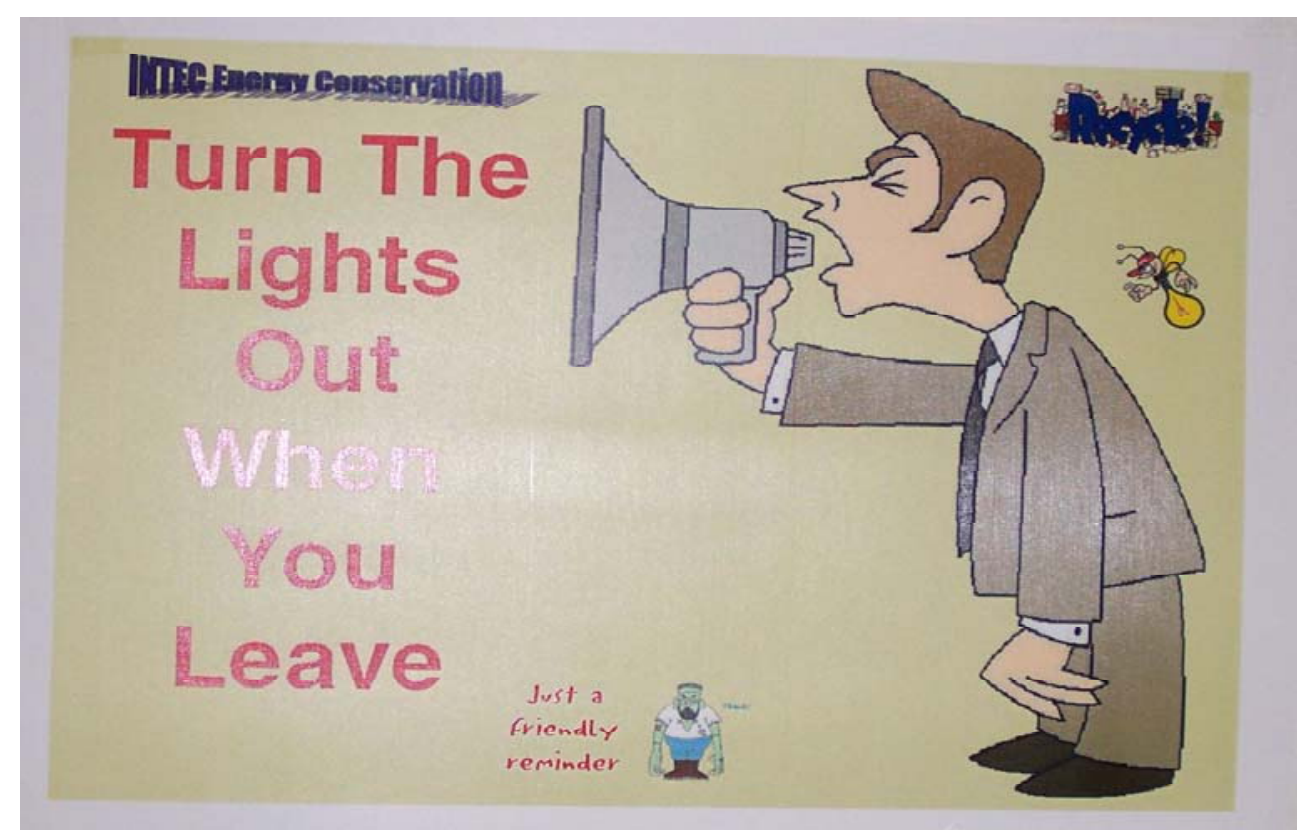

\section{Poster 8}

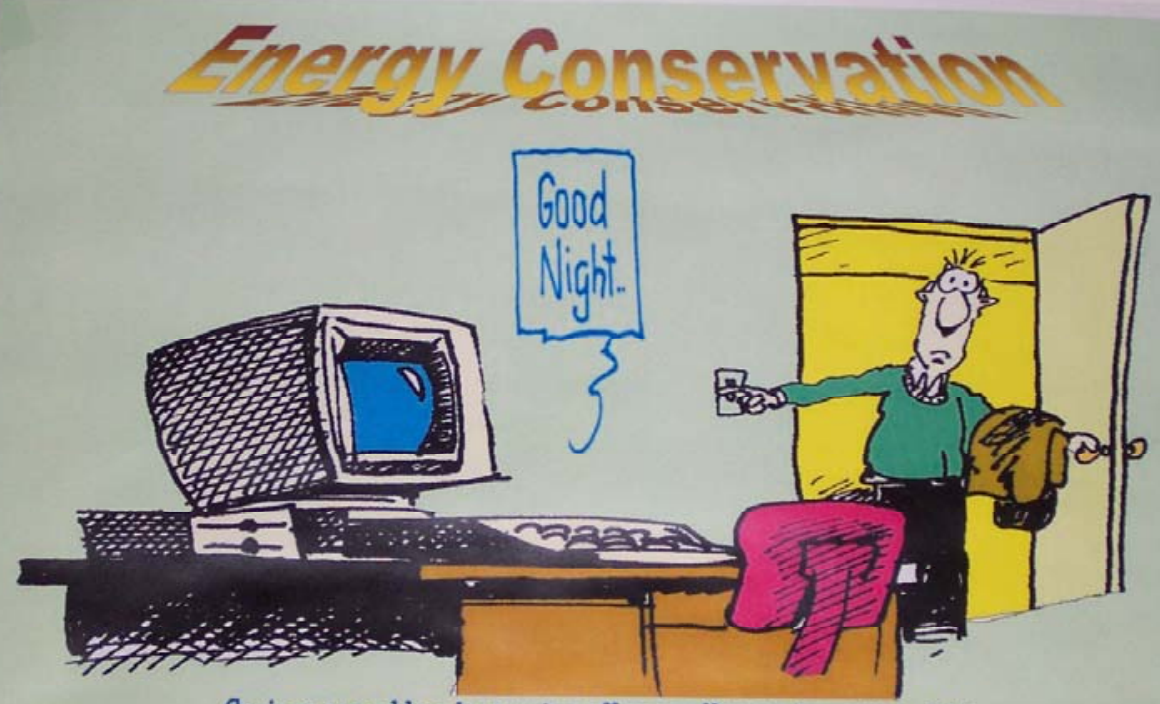

Savings can add up by turning off your office equipment at night.

Turn off your computer, monitor and printer at the end of the day at the power strip.

Most monitors come with power management features; talk to your staff's computer expert about activating these features.

Note that screen savers don't save energy; complex screen savers actually increase energy use. 


\section{Poster 9}

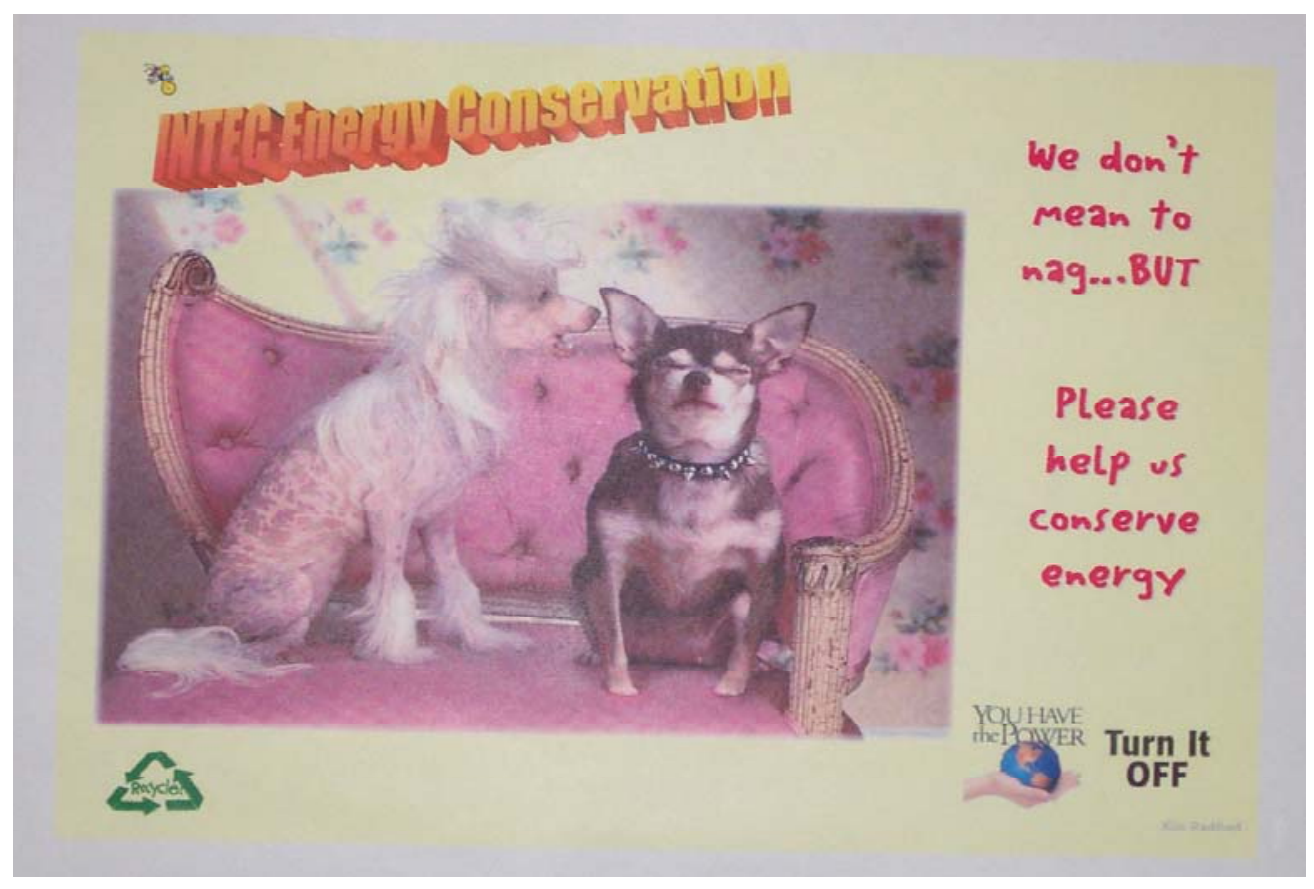

\section{Poster 10}

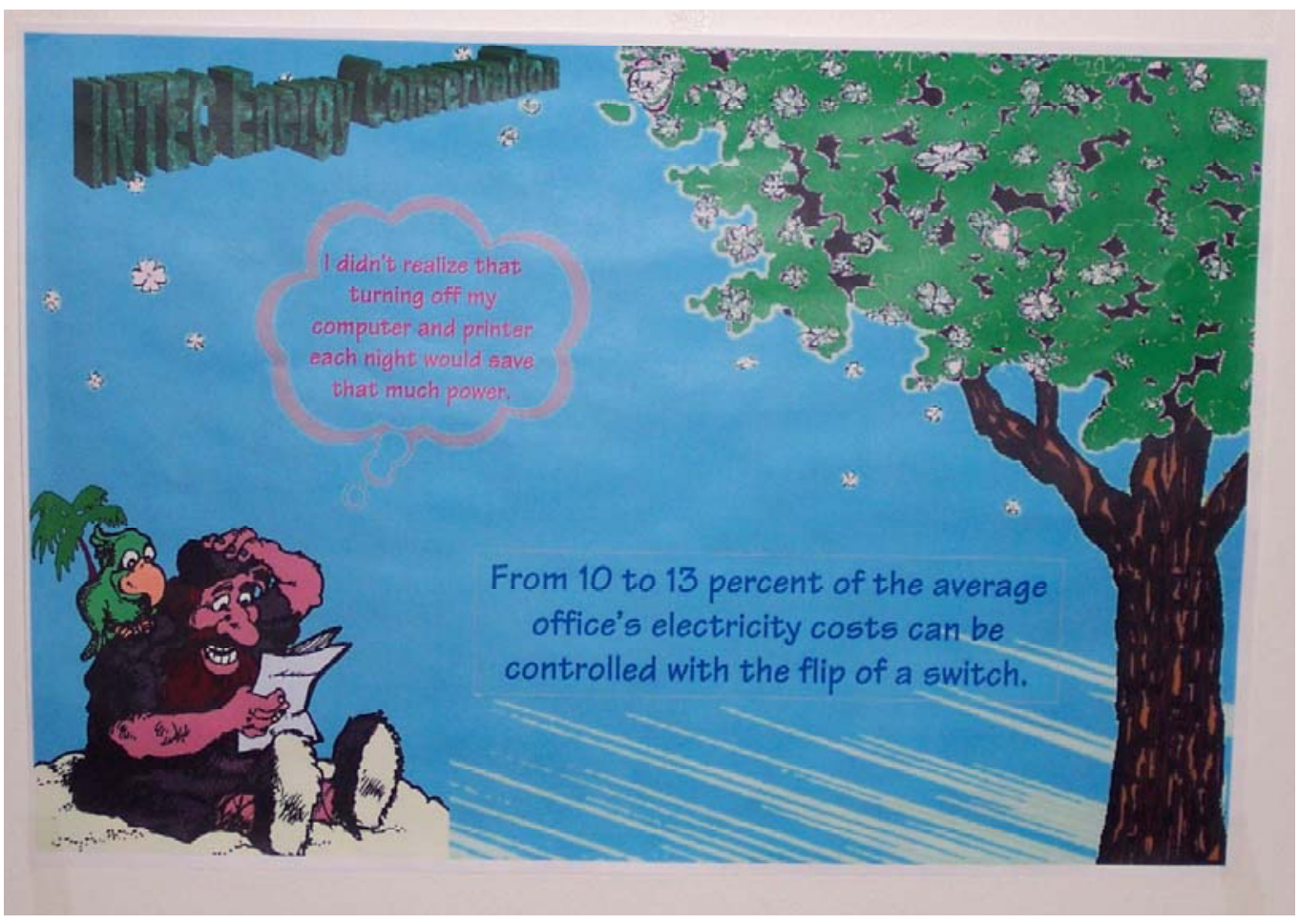




\section{Appendix B}

\section{Bar Charts Comparing Demand Usage}

from FY00 to FY03 
B-2 


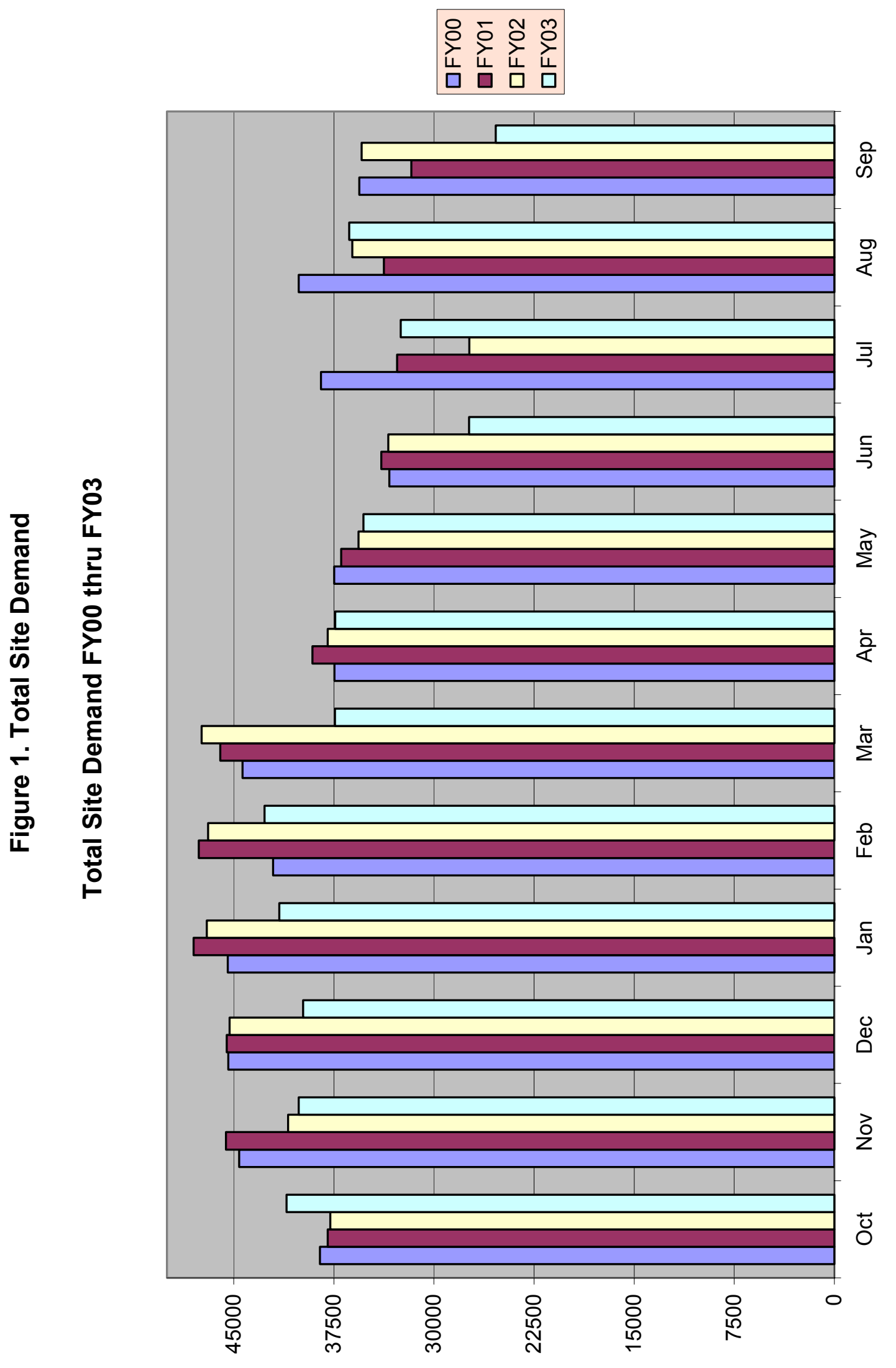




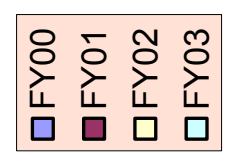

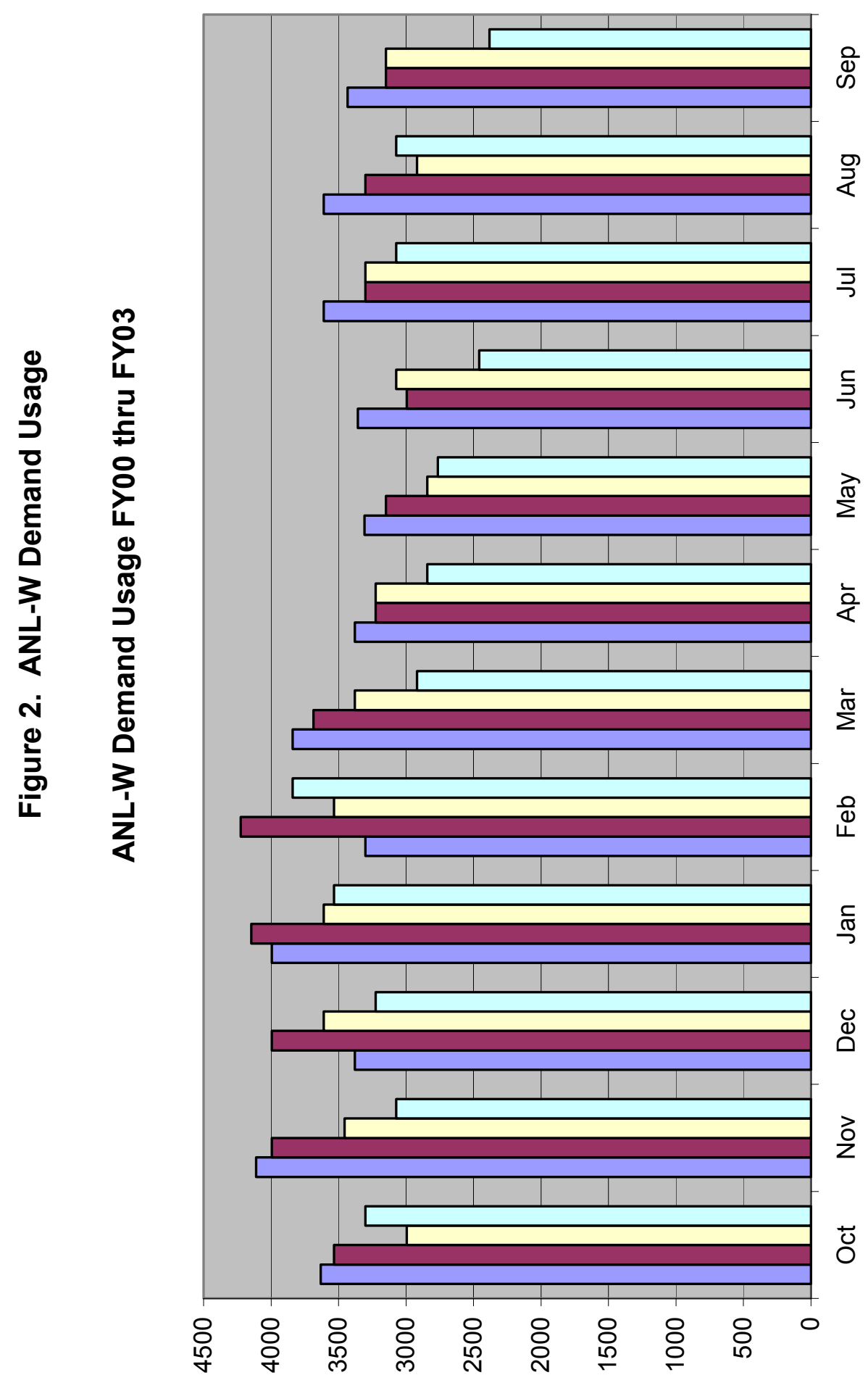




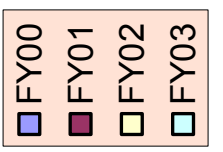

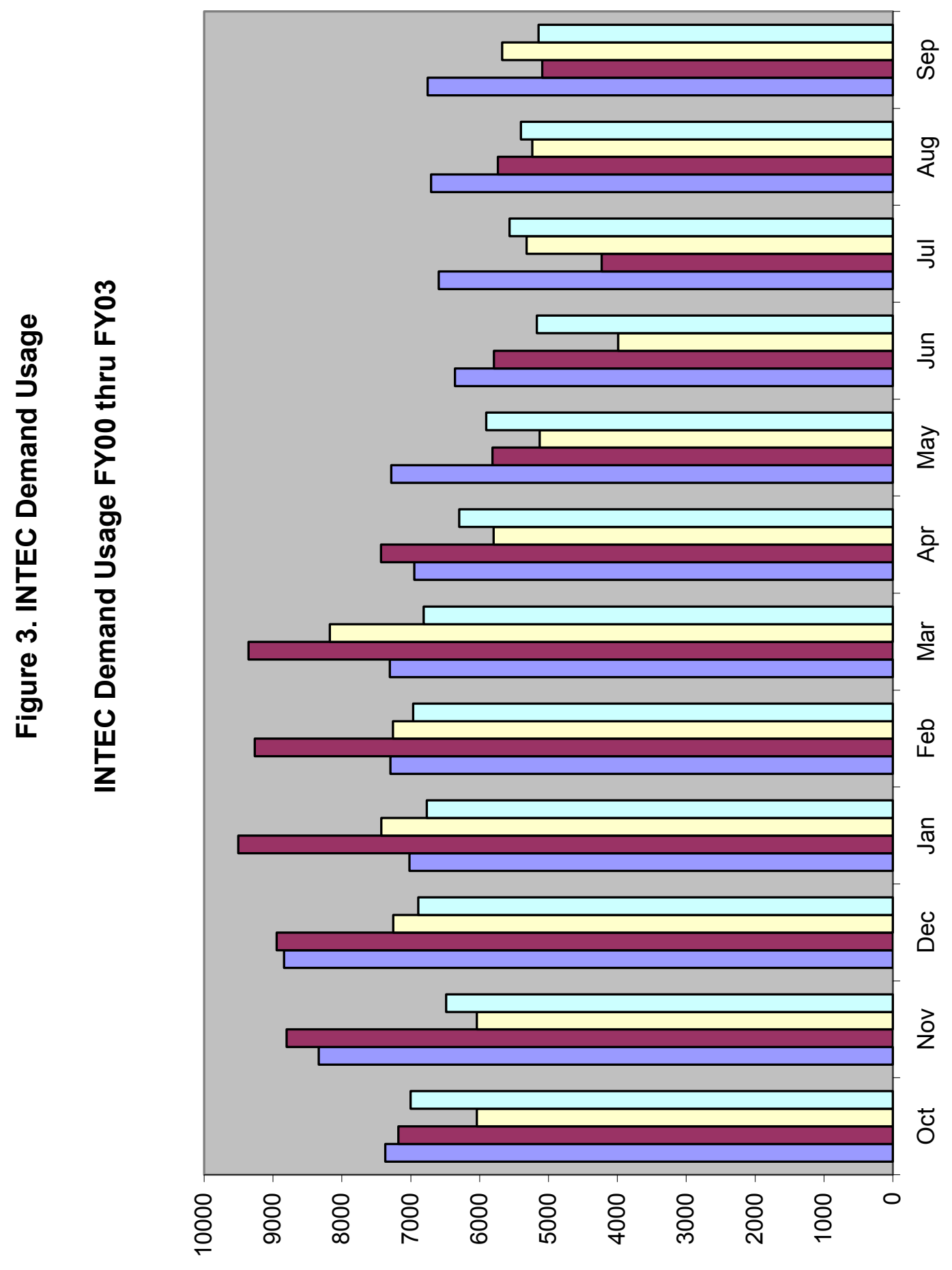

ñ 


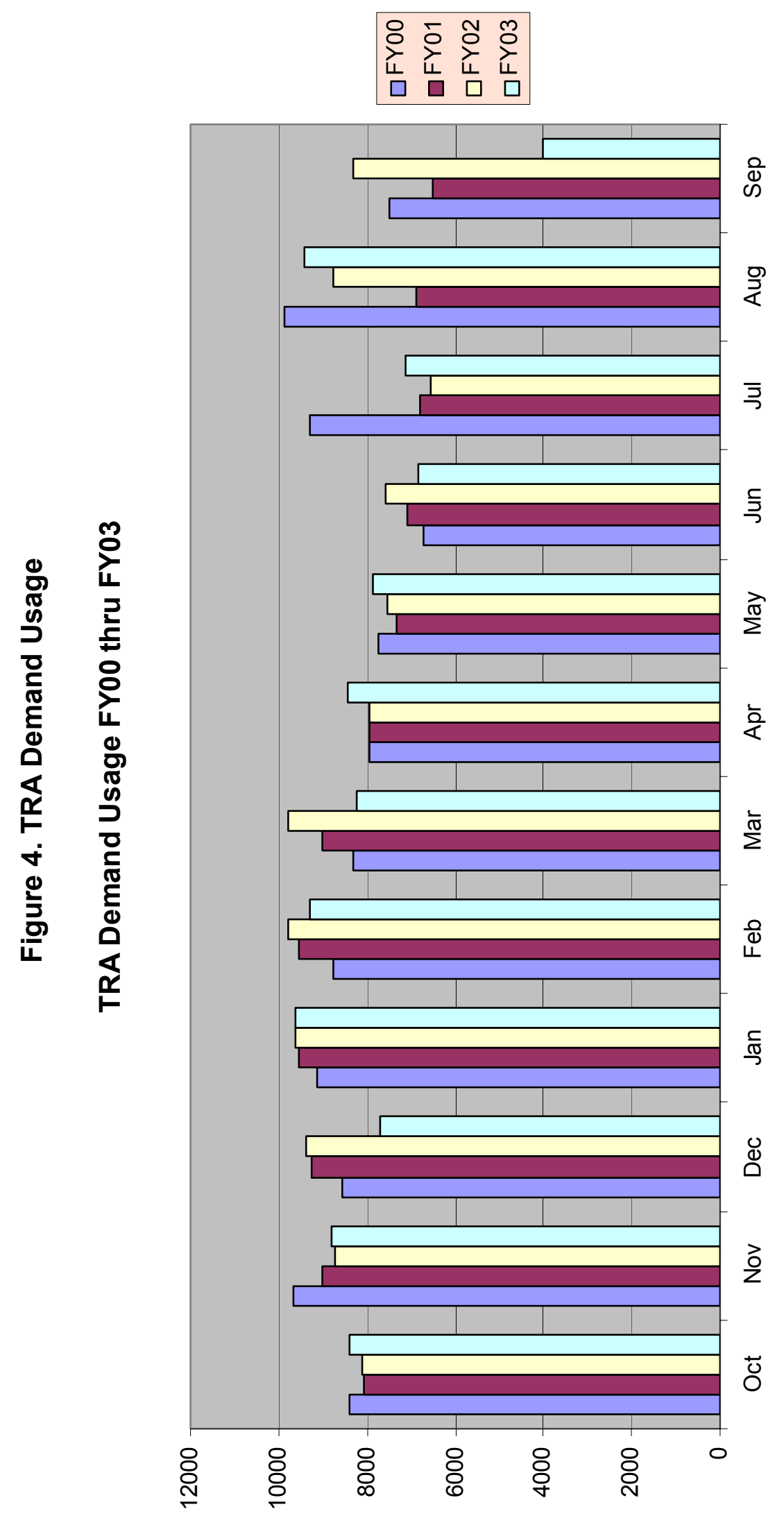




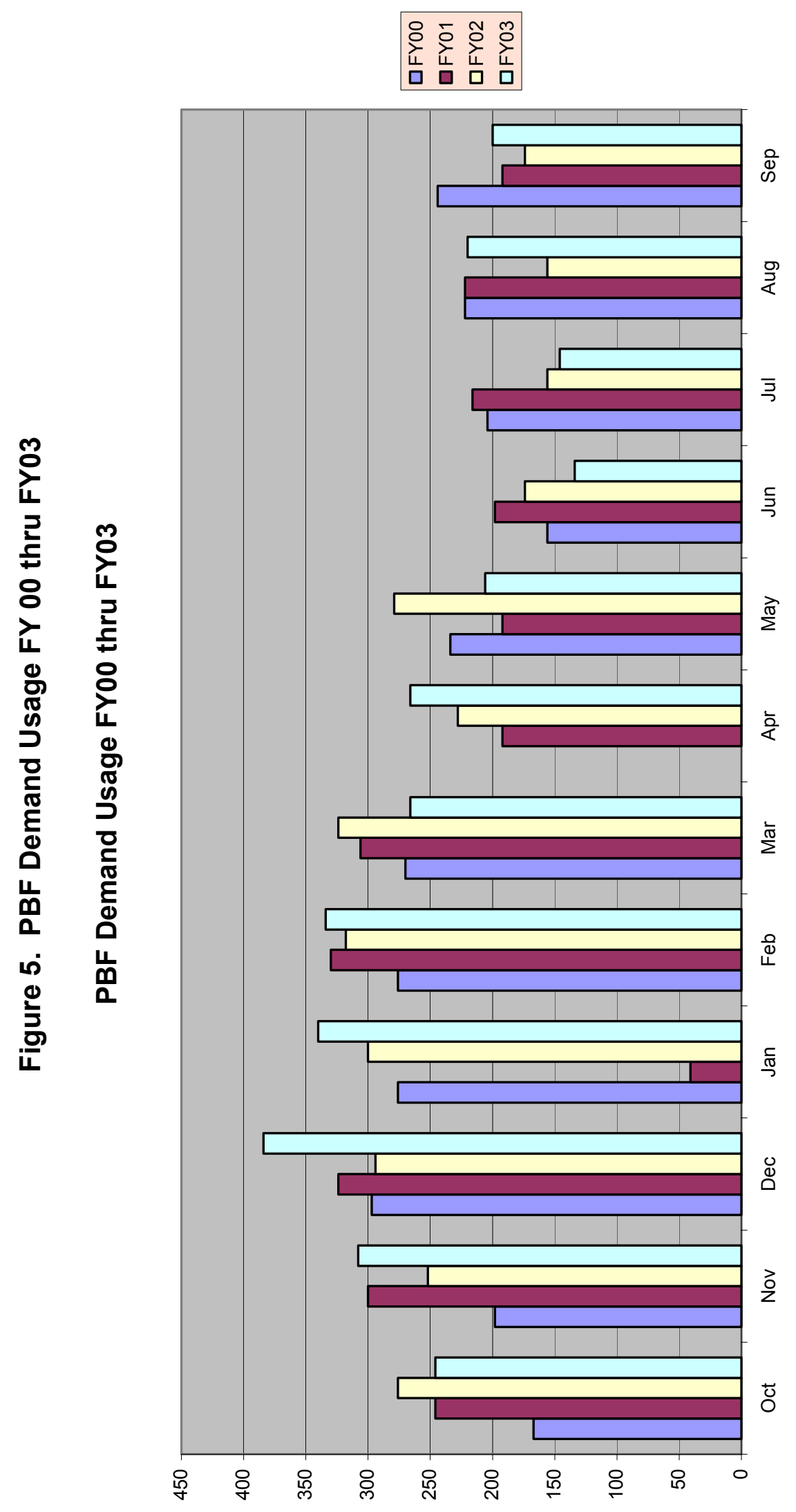

í 


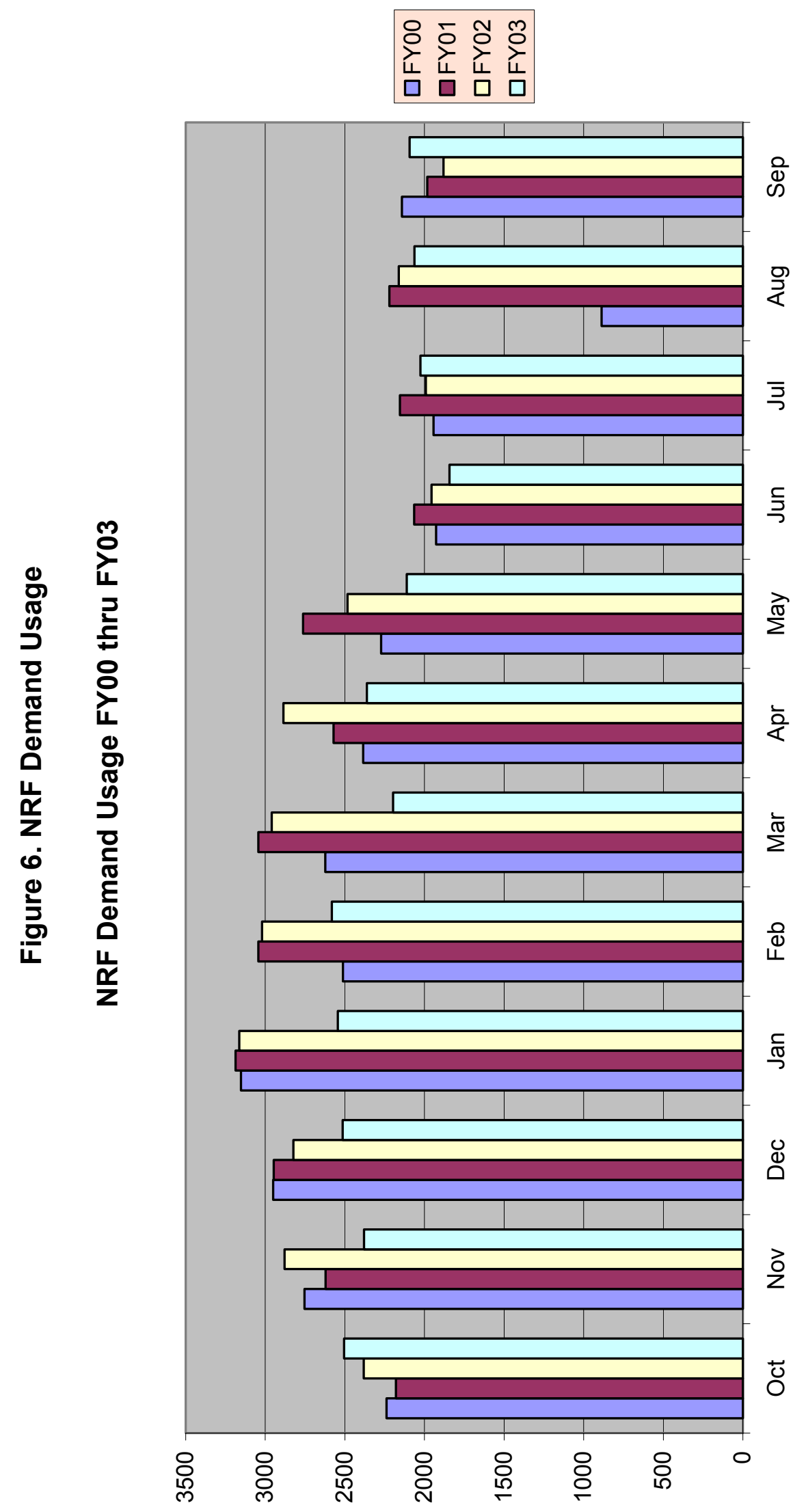




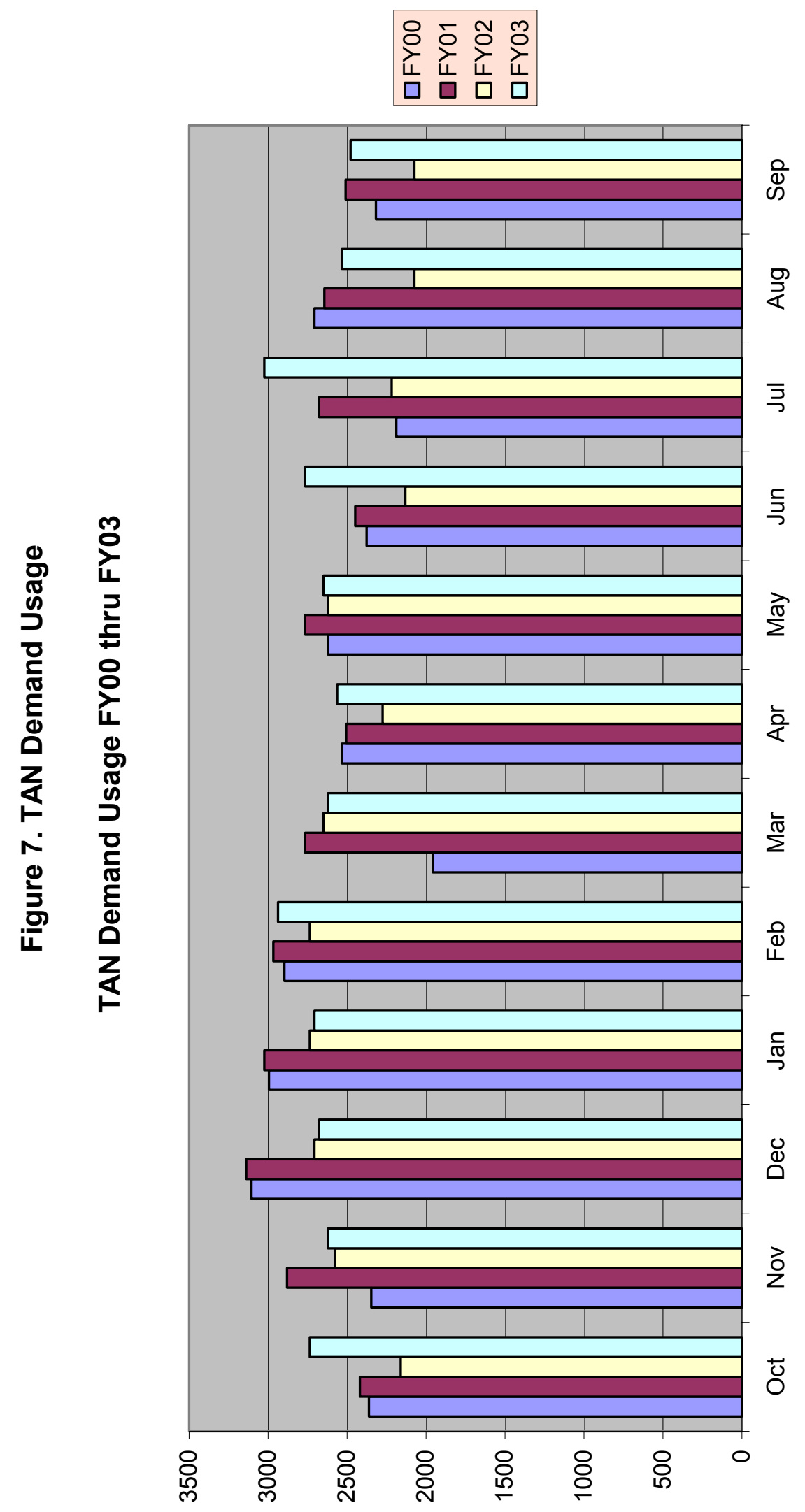

à 


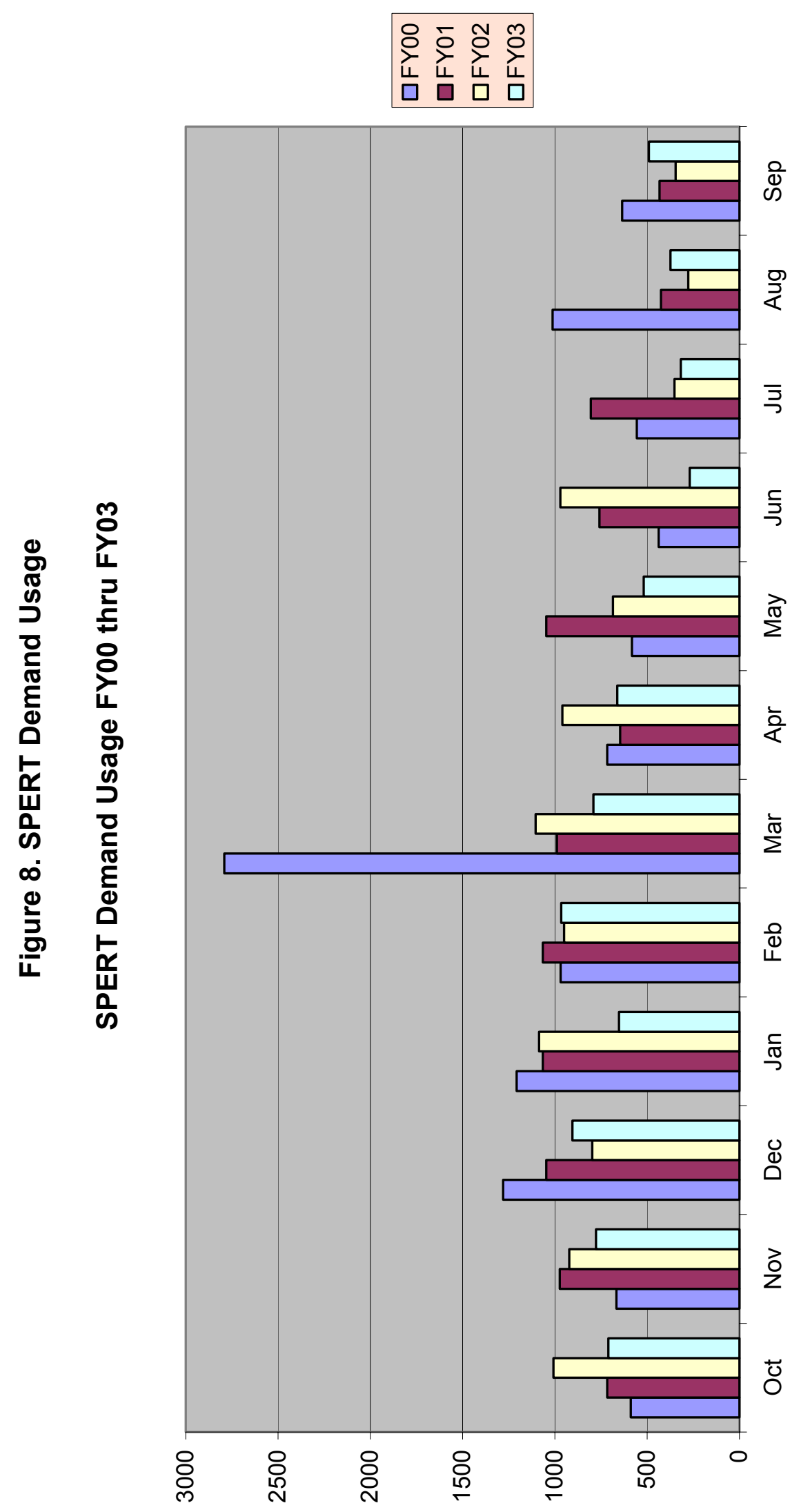




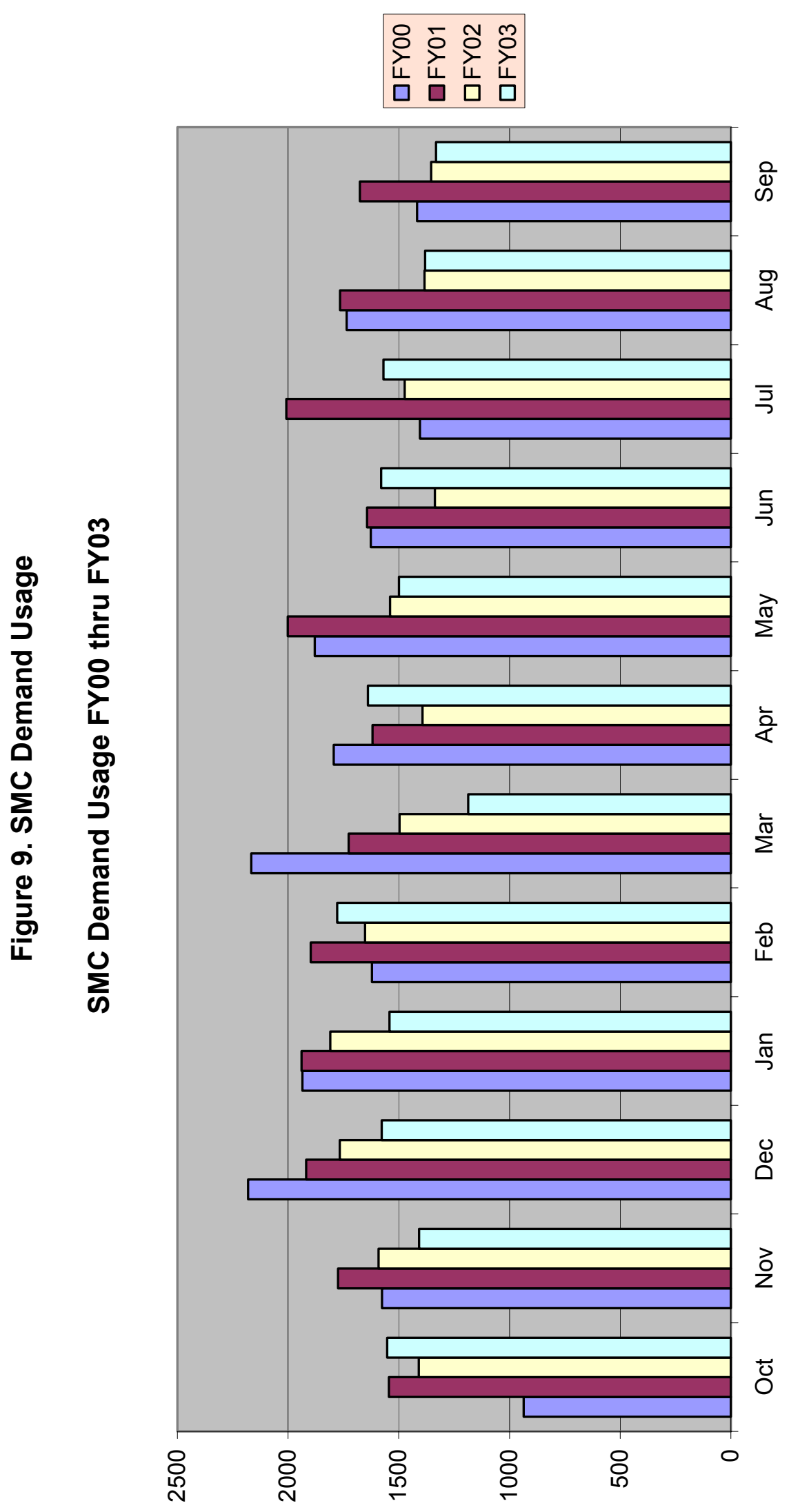




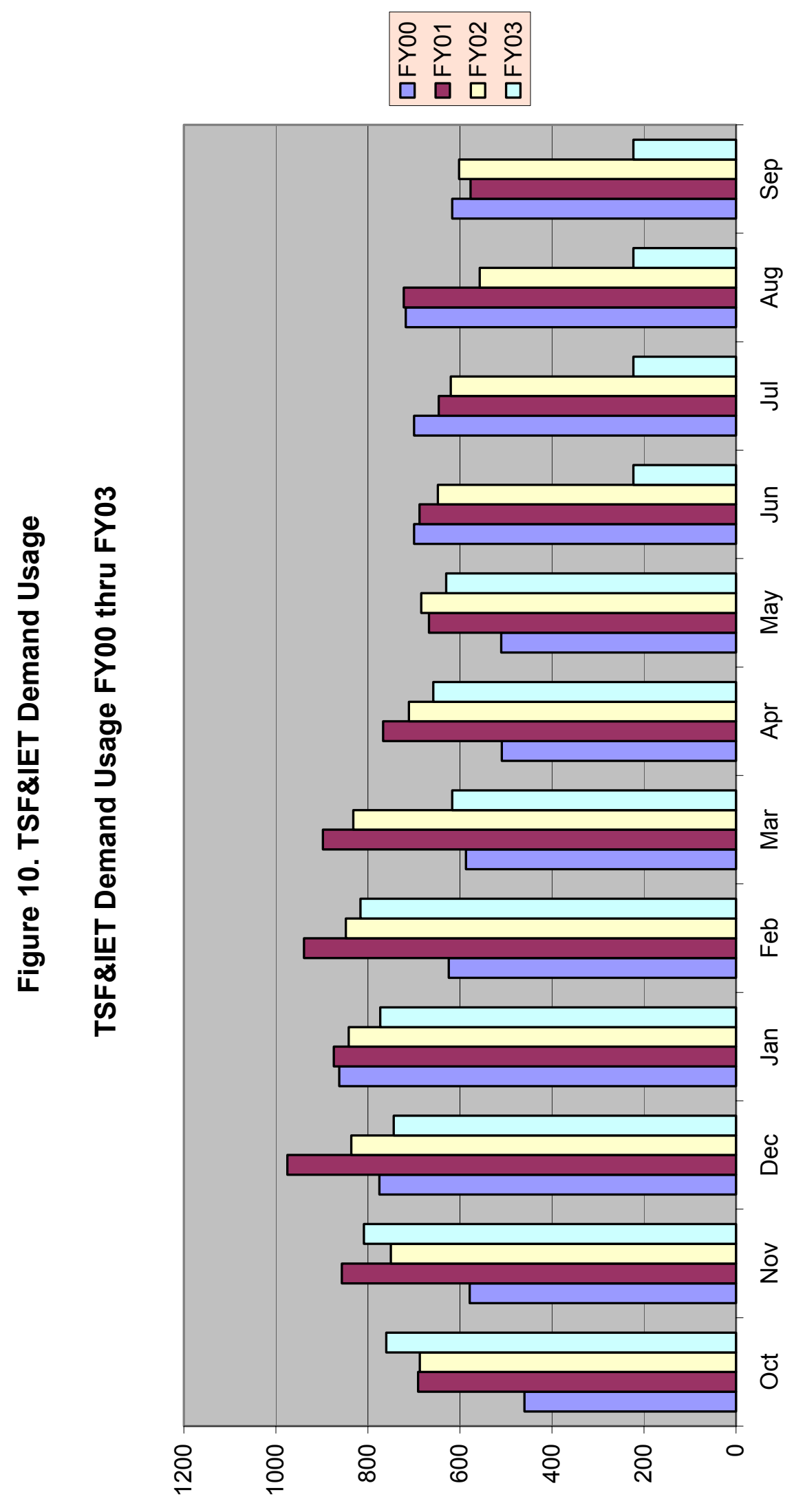




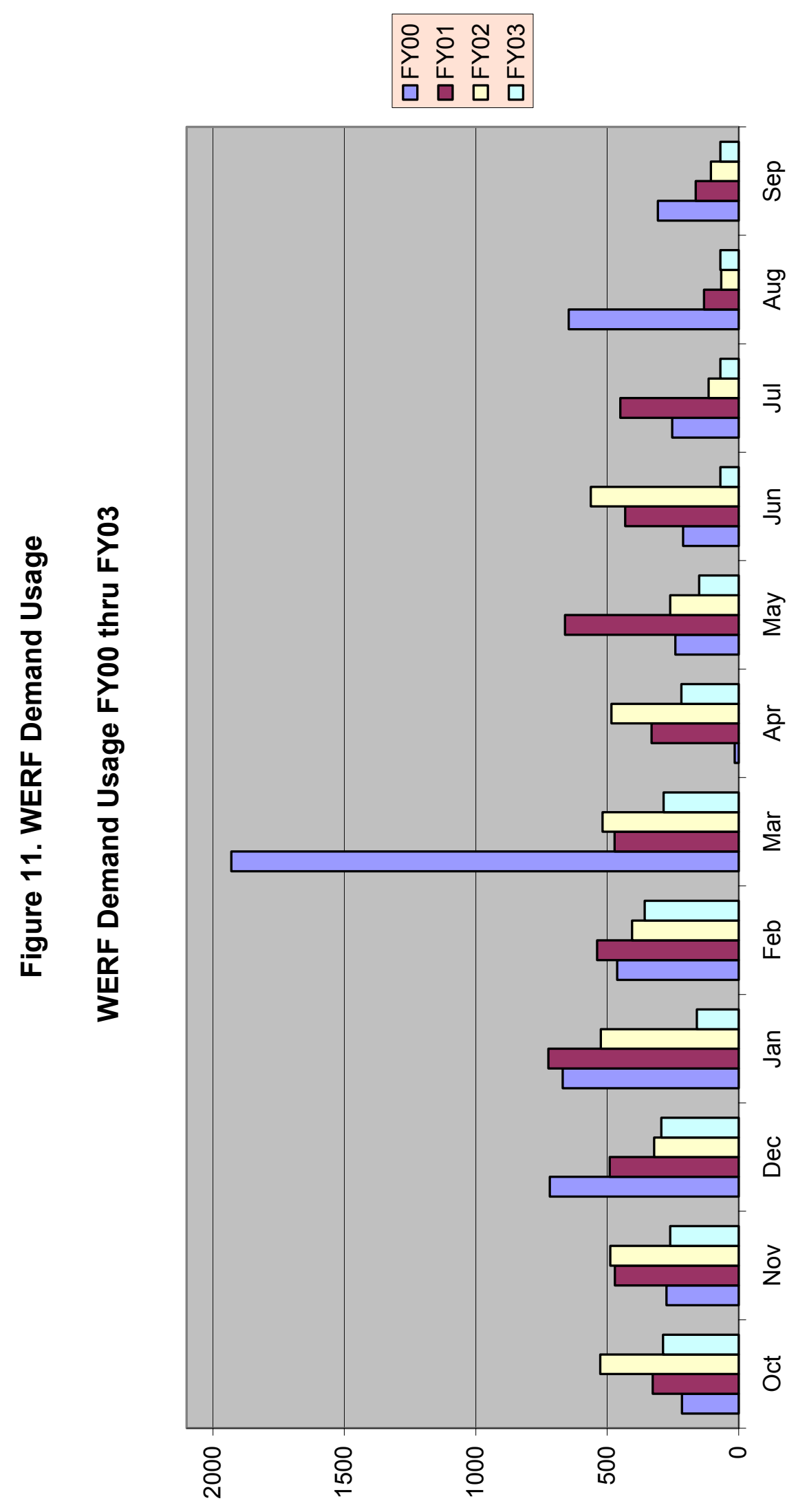




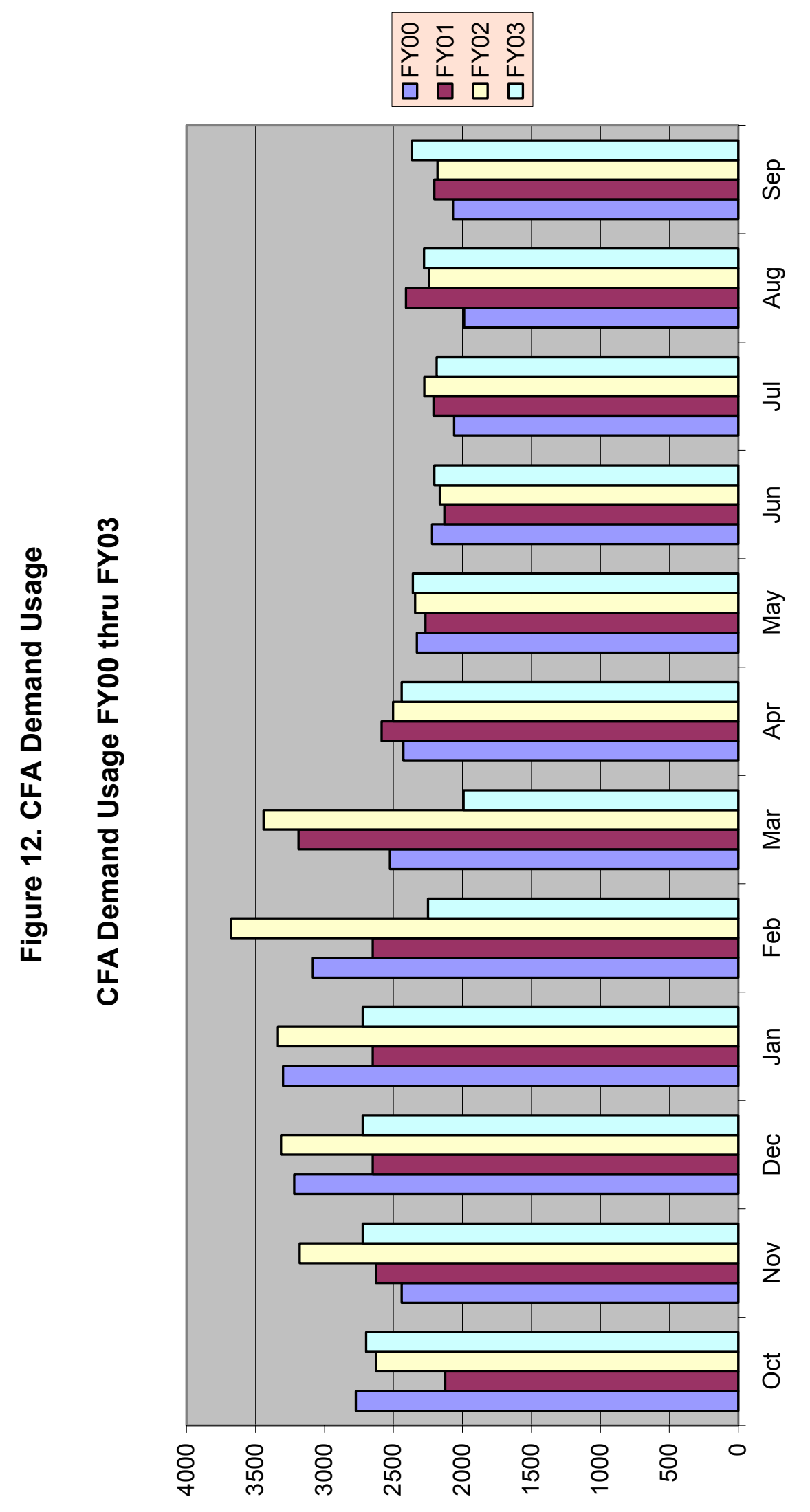




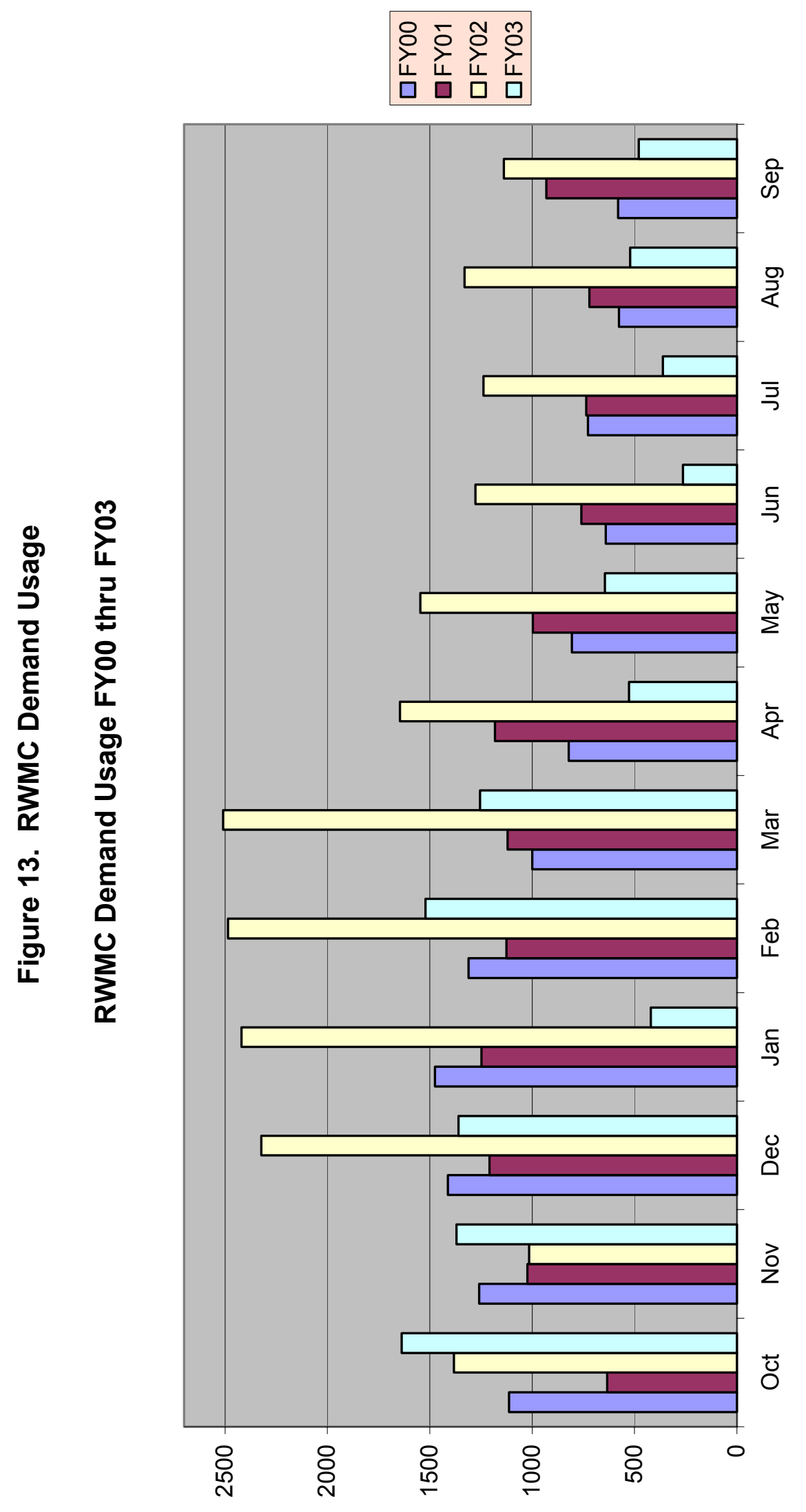




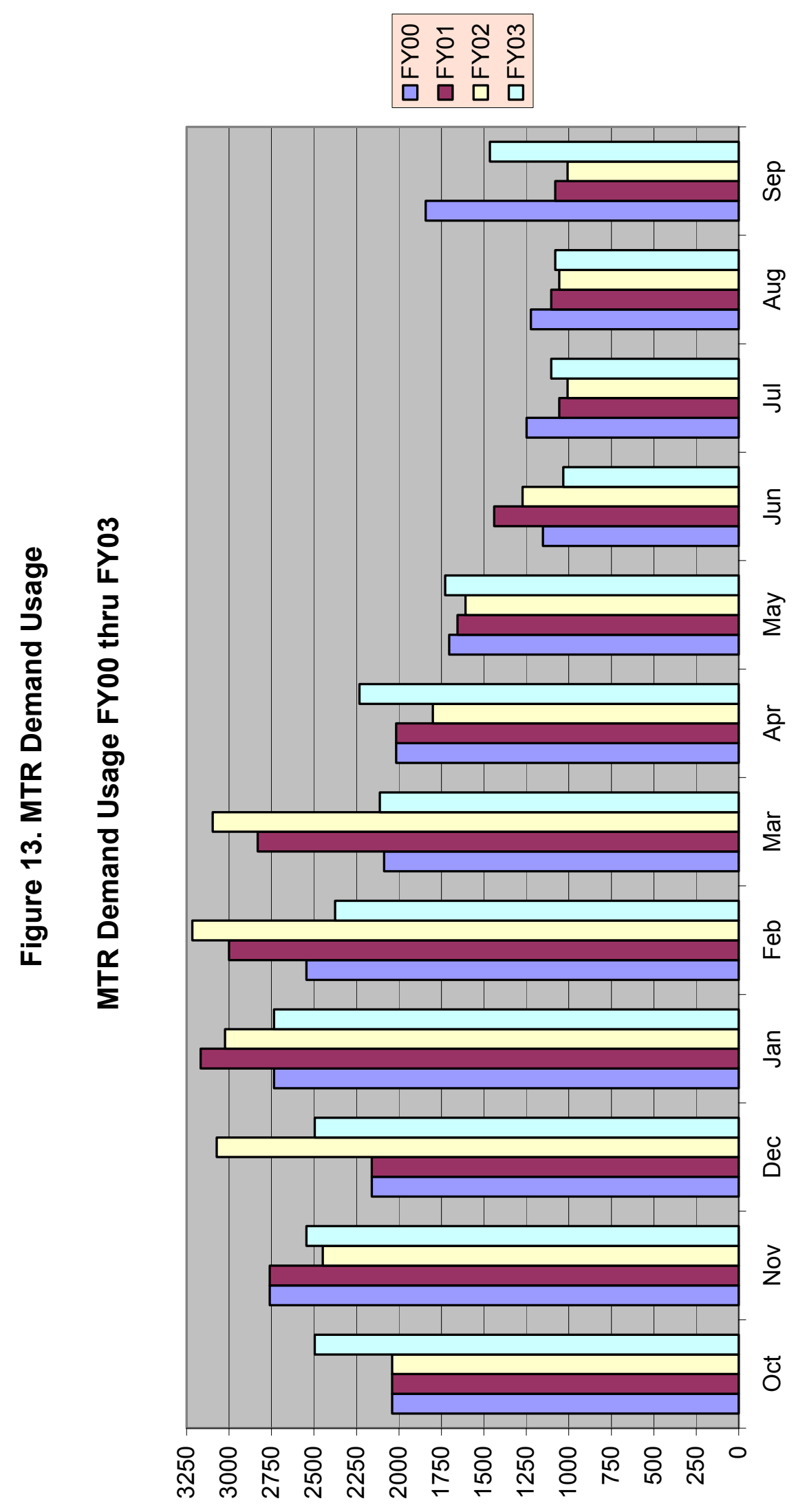




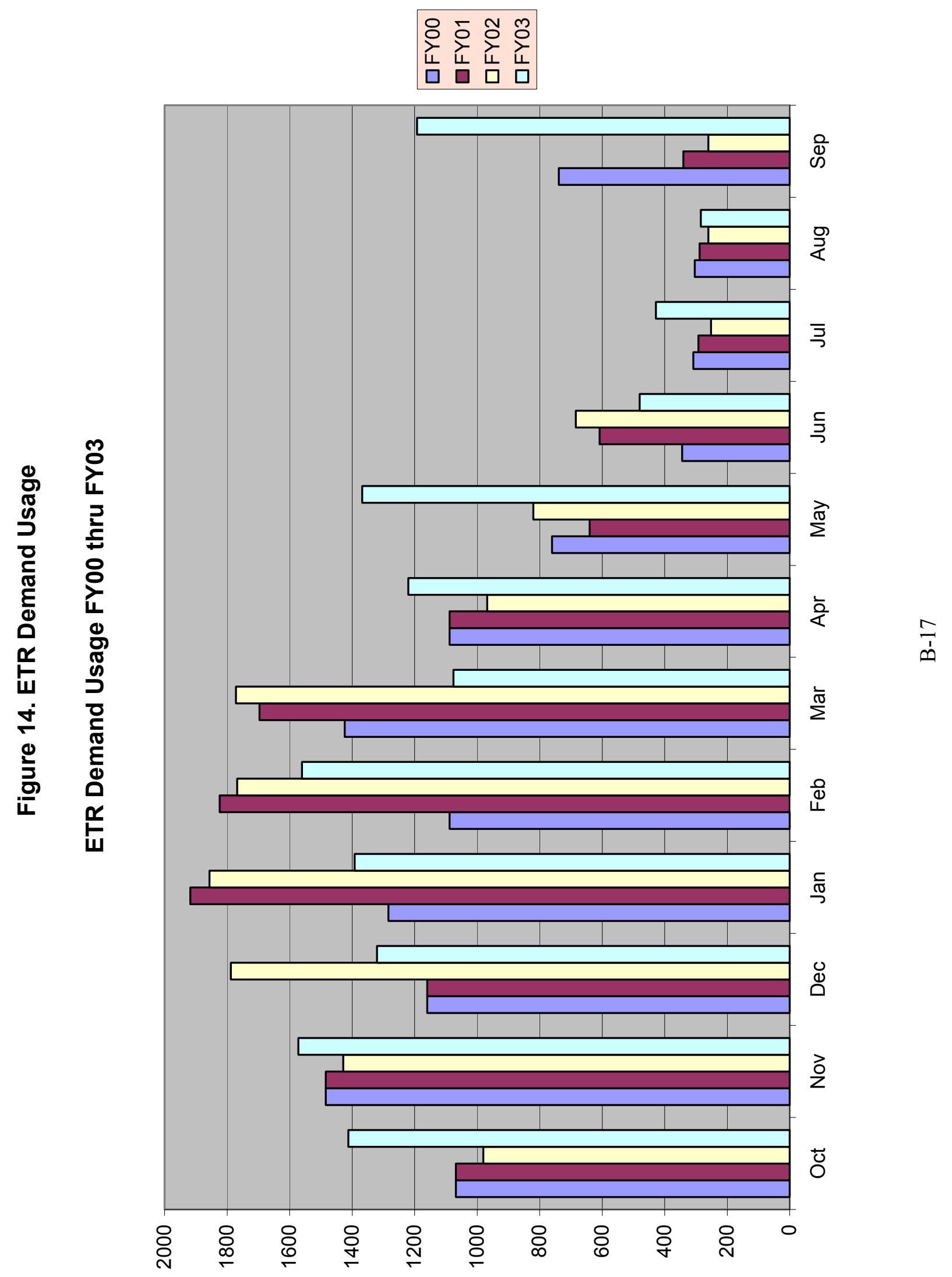




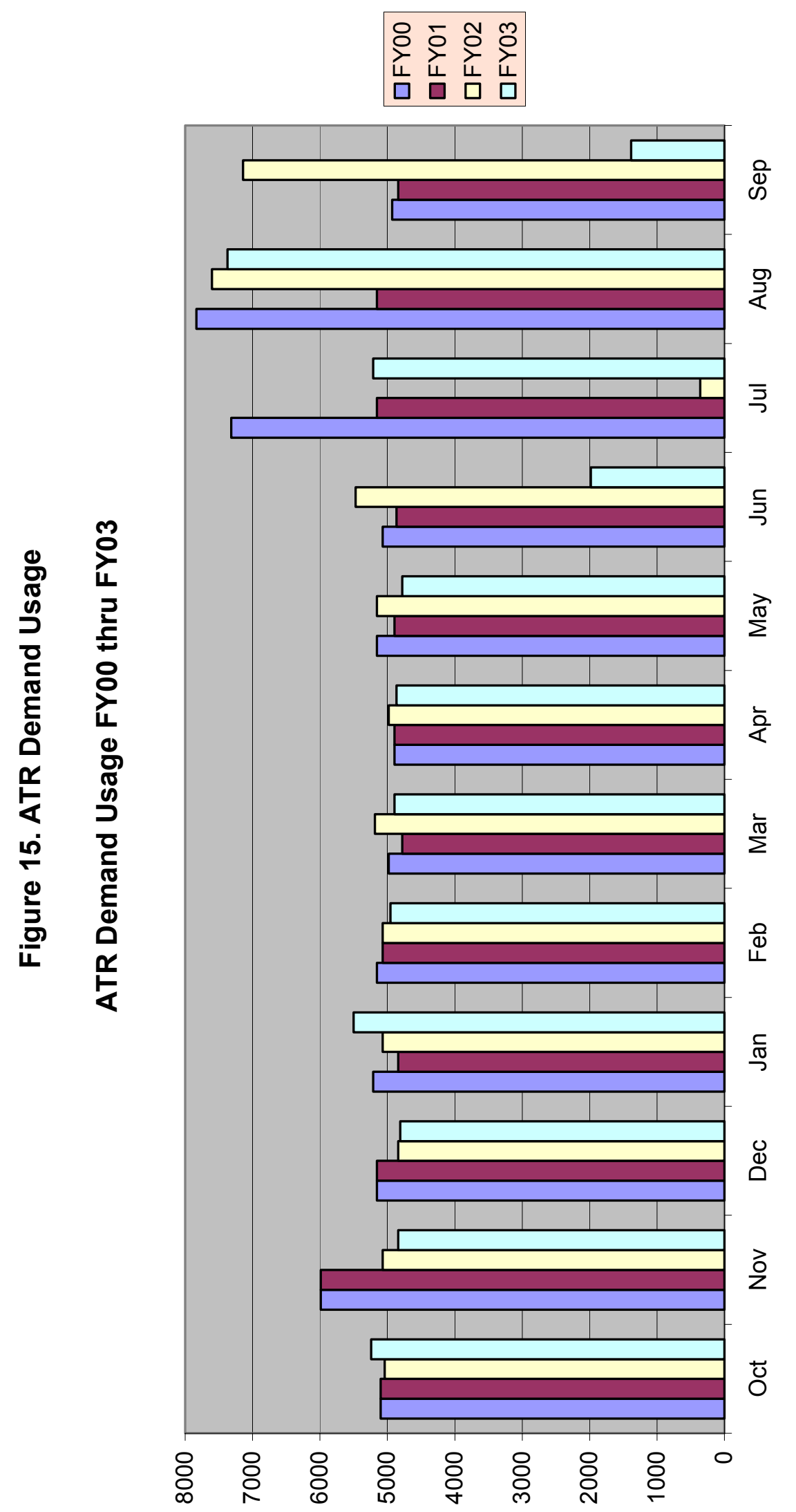

